\title{
HOTEL PERFORMANCE AND RESEARCH STREAMS: A NETWORK CLUSTER ANALYSIS
}

\author{
Sainaghi, R., Baggio, R., Phillips, P., \& Mauri, A. \\ International Journal of Contemporary Hospitality Management, 30(8), 2018. [forthcoming]
}

\begin{abstract}
Purpose

This article provides a review of hotel performance within the hospitality and tourism research domain. We use network analysis to examine two research questions. The first relates to ascertaining general trends within the hotel performance literature, and the second focuses on identifying the salient streams and sub-topics.
\end{abstract}

\section{Methodology}

Articles were selected according to three criteria: keywords, journals, and year of publication. The analysis embraces 20 years (1996-2015). These choices assure a wide coverage of the literature. Using these three criteria, the sample includes 1,155 papers.

For the analysis, we created a network of papers designated as nodes, and the citations among the papers as links. A network approach recognizes the internal structure of the network by identifying groups of nodes (papers) that are more densely connected between themselves than to other nodes within the network (modules, clusters or communities).

\section{Findings}

We found 761 papers that were "connected" studies within the network. By contrast, 34\% of sample (394 papers) consists of "unconnected" studies. Excluding outliers, the net sample was 734 articles. We identify 14 clusters, which we break down into several subtopics.

We conclude by providing some conclusions regarding trends and future research directions. With regards to salient topics, cross-citation and network analysis provide a detailed picture of where the literature comes from and where it currently stands. Conclusions are articulated at the theoretical and empirical levels.

\section{Originality}

Compared to previous hotel performance reviews, the approach followed by this study enables the discovery of an analytical research map, which is able to identify both clusters and sub-topics populating each segment. Researchers are able to position their work and identify issues that are in growth and decline.

KEYWORDS: Hotel; Performance; Network cluster analysis; Cross-citation analysis

\section{Introduction}

Hotel performance and competitive advantage has been gaining increasing momentum within the academic literature (Leonidou et al., 2013). Hotel firms need to innovate in order to face internal and external environment evolution, or they will not prosper (Sainaghi et al., 2017). These driving forces have led to academic inquiry, which in turn, has shed light by providing published reviews in a number of hospitality and tourism journals (as discussed later and as reported in Appendix 1). 
By way of illustration, Köseoglu et al. (2016) found 190 reviews published between 19982015 with the temporal trend showing a progressive increase. This study will analyse prior theme-focused reviews that are published in leading hospitality and tourism journals, with results categorized by discipline and topic. Within "management and business", marketing accounts for the highest percentage $(39 \%)$ of reviews, followed by information systems $(13 \%)$, human resource management $(10 \%)$ and finance $(10 \%)$. There is only one paper exploring the hotel performance research stream (Sainaghi, 2010a).

Despite the paucity of reviews, hotel performance attracts considerable interest between academics and practitioners. This is a consequence of management teams wanting to achieve superior performance and gain insight into the processes and practices that drive the core strategy (Sainaghi et al., 2013). A more recent literature review, includes 978 articles pertaining to "hotel and performance" and, more importantly, $48 \%$ of them were published in the last four years (Sainaghi et al., 2017). This upward trajectory is related to the relevancy of performance measurement for all hotel stakeholders with profit and non-profit objectives (e.g. Alrousan et al., 2015). Furthermore, a myriad of issues need to be considered when assessing current performance, including long-term objectives and the current competitive situation (Bernini and Guizzardi, 2015). New perspectives and streams of research continue to emerge (Peiró-Signes et al., 2015). Issues relating to the importance of discovering papers' trends have been of particular interest in the literature with Xiao and Smith (2008) highlighting that the various knowledge sub-fields can assist in understanding basic issues and charting the evolution of theory and practice

High levels of performance are a salient output for hotels (Phillips, 1999), so a focus on "hotel performance" captures two critical terms worthy of detailed investigation. So, in light of such observations together with the need for advancement in pace of theory and practice for hotel performance, we believe that it is an appropriate time to take stock of the research generated over the last two decades.

The focus of this paper is, therefore, on two key research questions (RQ). RQ1 What are the main trends within the network of papers pertaining to hotel performance? RQ2 What are the main research streams within the hotel performance field and what are the relevant subgroups?

\section{Literature review}

This paragraph is structured around two topics. Previous hotel and performance research studies are identified and analysed (\$2.1). Then we discuss the research questions, and a bibliometric approach is proposed, based on network analysis $(\S 2.2)$.

\subsection{Hotels and performance}

As reported in the introduction, there is a growing number of reviews published in the hospitality and tourism field. Previous reviews include the works of (Sainaghi, 2010a; Sainaghi 2010b; Sainaghi et al. 2013; Pnevmatikoudi and Stavrinoudis, 2016; Sainaghi et al. 2017). Interesting, Köseoglu et al. (2016) found only one paper which focuses on hotels and performance (Sainaghi, 2010a), which identifies two areas of enquiry: performance measurement systems and determinants of results. The goal of the second review (Sainaghi 2010b) considers the focal point of "research styles" with three different approaches proposed. They consider independent and dependent variables, geographic scope, sample size, type of evidences used, and year of publication. Sainaghi et al. (2013) paper acts as a conduit between his previous two works. In fact, this study is based on the balanced scorecard (as Sainaghi, 2010a) and focuses on geographical areas (as Sainaghi, 2010b). The review by 
Pnevmatikoudi and Stavrinoudis (2016) classifies different performance variables, and describes prior studies, as complex and manifold. Finally, Sainaghi et al. (2017) is the most recent review and incorporates 978 papers and adopts a computer-aided text analysis.

To appreciate the developments in hotel performance it is necessary to chart developments at the individual study level too (see Appendix 1). During the 1990s the focus was very much highlighting the advantages of successful balanced scorecard (BSC) implementation, which could bring both quantitative and qualitative benefits (e.g. Denton and White, 2000; Doran et al, 2002; Huckenstein and Duboff, 1999). During the first decade of the third millennium, outputs were predominantly web based and marketing focus (e.g. Feng et al, 2004; Kim et al, 2004; So and Morrison, 2004). This illustrated the potential of the BSC as a strategy tool, which could pervade organisational functions by moving beyond the sole financial regime, such as HRM (McPhail et al 2008; Nazarian et al 2017; Salehzadeh et al. 2015 Salehzadeh et al. 2015). Kang et al (2015) corporate social responsibility study strengthens links with the sustainability agenda. This is an area of significant potential, as hotels need to incorporate sustainability into their strategies. Hotels need to nurture partnerships as they address concerns about environmental and socio-economic issues. As a body of research matures, researchers need to break new ground. Hotel performance is no different and studies such as Salehzadeh et al. 2015 which investigates the effect of spiritual leadership on performance is noteworthy. Nazarian et al (2017) study investigates the effect of national culture on organisational culture and this has solid foundations for future studies. This study leads to another finding that being the global nature of research. Prior studies have moved outside of the traditional western context with studies in the context of China, Iran, Caribbean, United Arab Emirates, Korea, and Croatia. As competition increases by global brands, emerging economy hotel brands need to increase expansion activities. Of paramount importance is the need to enhance levels of hotel performance.

Collectively, the five hotel reviews reinforce the centrality that trend analysis plays for academia and practitioners. This is unsurprising given the continued flux of the hotel business environment, so they need to identify the salient dimensions to operationalize the hotel performance constructs. For this reason, the first research question focuses on trends.

Another pertinent observation refers to the relevancy that the classification of topics assumes. Three prior reviews (Sainaghi, 2010a, 2010b; Sainaghi et al., 2013) employ the BSC perspectives in order to distinguish between different issues, while Pnevmatikoudi and Stavrinoudis (2016) develop a performance framework built around financial and nonfinancial indicators. Finally, Sainaghi et al. (2017) adopt an original method investigating approaches and disciplines. The present article explores topics and sub-topics (second research question), using a cross-citation analysis (as later explained). Furthermore, while the majority of these studies use a deductive approach, applying ex-ante models, such as the BSC or the financial and non-financial framework, this article adopts an inductive approach, based on content analysis and network theory (as later presented). In terms of identifying the salient streams and sub-topics, our brief review overview highlights streams and some sub-topics, but there is a need to delve much deeper. A cross-citation and network approach can facilitate this.

\subsection{A cross-citation and network approach}

In order to identify relevant topics within the hotel performance literature, this paper applies a bibliometric approach (Hall, 2011) and in particular a cross-citation analysis (Wang et al., 2012). As illustrated in Appendix 1, traditional qualitative literature reviews tend to be limited in the volume of data they can handle (sample size) and they are reliant to subjective 
judgments (García-Lillo et al., 2016). In comparison, a bibliometric citation analysis can consider large datasets for quantitative analysis (Wardle and Buckley, 2014) and, additionally, citations are objective measures (Kim et al., 2009; Leung et al., 2017).

Cross-citation is part of the relational approach (Benckendorff and Zehrer, 2013), which is able to explore relationships among published work. The basic idea is that: researchers will cite papers they believe to be important for their research (Benckendorff, 2009). Therefore, analysing citation patterns is a way of identifying communities or groups of researchers pertaining to the same or adjacent fields (Baumgartner and Pieters, 2003). As reported in the recent study of Köseoglu et al. (2016), relational approach is marginally adopted in hospitality and tourism (4\%). For this reason, the present article makes a contribution to this methodological gap.

At the nucleus of the relational approach, Wang et al. (2012) distinguish among three different techniques: co-citation, coupling and cross-citation. Co-citation analysis use pairs of documents which often appear together in reference lists and have something in common (Xiao and Smith, 2008). This methodology focuses on references and, in this sense, explores the pillars of a specific research stream (Benckendorff and Zehrer, 2013). Two articles are bibliographically coupled if their reference list share one or more of the same cited documents (Yuan et al., 2015). Two papers must cite the same source to be coupled, whereas co-citation rely on any papers listed in another's reference list. The coupling strength increases as the number of citations they share. Finally, cross-citation analysis assesses the relationships of articles and helps to identify patterns (Howey et al., 1999). Two studies are cross-cited, if one of them cites the other one. This methodology differs profoundly from the first two. In fact, while co-citation and coupling-citation both focus on the reference structure, cross-citation analyses relationships among contributes of a sample of papers. We seek to identify a community of researchers to provide further insights, so a cross-citation approach is adopted in this study.

To operationalize a relational approach, previous studies adopted the network theory (Benckendorff and Zehrer, 2013; Gomezelj, 2016; Köseoglu et al., 2015; van der Zee and Vanneste, 2015; Ye et al., 2013; Yuan et al., 2015). In fact, this methodology with an interdisciplinary approach helps to represent and analyse relationships among authors, (Oviedo-García, 2016).

The use of networks within a hospitality and tourism context is attracting attention (Baggio et al., 2010; Baggio and Sainaghi, 2011; 2016; Sainaghi and Baggio, 2014, 2017; Timur and Getz, 2008). Some additional details about the network technique adopted in this study are given in the methodology section $(\$ 3.2)$.

\section{Methodology}

This study performs a cross-citation analysis within the stream of "hotel performance" research. Two central themes were relevant: i) the sample selection, and ii) the network and cluster analysis.

\subsection{Sample selection}

Articles were selected according to the following criteria: i) keywords, ii) journals or databases, and iii) year of publication. Each point will be elaborated later and the choices made are compared with studies reported in Appendix 1.

The use of keywords is common: excluding the "not specified" papers, $79 \%$ of analysed reviews adopt keywords. Generally speaking, studies are straightforward and relate to the specific research object. There is a wide consensus in the use "hotel" and "performance" in performance related studies (Sainaghi, 2010a, 2010b; Sainaghi et al., 2013, 2017; Pnevmatikoudi and Stavrinoudis, 2016). For this reason, this paper replicates this choice, 
which assures comparability. Performance measurement usually includes two different research streams: on one side papers that propose new systems of indicators (performance measurement systems in a strict sense) (Brander Brown and McDonnell, 1995; Denton and White, 2000; Harris and Mongiello, 2001; Phillips, 1999; Sainaghi, 2010a; Yilmaz and Bititci, 2006) or, on the other side, articles researching antecedents or determinants of performance (performance measurement systems in a broader sense) (Atkinson and Brander Brown, 2001; Bergin-Seers and Jago, 2007; Mia and Patiar, 2001; Sainaghi et al., 2013, 2017).

Concerning the second point (journals), some previous reviews explicitly focus their attention on tourism or hospitality sector (e.g. Chan and Hsu, 2016; Jang and Park, 2011; Lucas and Deery, 2004; Phillips and Moutinho, 2014; Yoo et al., 2011), analysing solely leading or relevant journals. However, the majority of previous reviews (53\% in Appendix 1) apply selected keywords to some databases (Scopus, Science Direct, Business Source, EbscoHost) (Gross et al., 2013; Hua, 2016; Sainaghi, 2010a, 2010b; Sainaghi et al., 2017; Sourouklis and Tsagdis, 2013; Tsai et al., 2011). This second choice broadens the number of journals, which is a relevant point for the field of performance measurement. In fact, the recent Sainaghi et al. (2017) study clearly demonstrates the relevance of non-tourism, non-hospitality and nonleading journals. Their sample includes 978 articles with $585(60 \%)$ being "non-tourism" papers and, "non-leading" journals accounting for 600 papers $(61 \%)$. Given the relevance of "non-hospitality", "non-tourism" together with "non-leading" journals, the sample included these outputs. This empirical study was carried out at the beginning of August 2016 and two keywords ("hotel and performance") were researched in abstract, title and keywords in the Scopus database. Only journals published in English were included in the sample. Concerning the time horizon, the analysis embraces 20 years, from 1996 to 2015. These choices assure an expansive coverage of the literature and in line with previous reviews. In fact, the sixteen reviews analysed (excluding the 5 papers where the time horizon is not specified, Appendix 1) embrace on average 18.7 years. Using these three criteria, the sample includes 1,155 papers.

All the papers were analysed to ascertain their relationship with the "hotel performance" research stream. Only articles that explore determinants of results or propose performance measurement systems were included in the final sample. This choice is coherent with previous studies (Appendix 1) and in particular with the study of Sainaghi (2010a). 268 papers were excluded (23\%). It is interesting to note that $90 \%$ of these outliers $(241)$ are "disconnected papers". Therefore, the proposed methodology (cross-citation) helps researchers to verify the relevance of selected keywords. This is reasonable, in fact if some papers are outliers (not relevant for a specific research stream), they are not cited by other studies and therefore they remain "disconnected". Table 1 reports the sample size. Net sample counts 887 papers, $153(17 \%)$ are disconnected (and therefore not included in the clusters reported in the findings section), while 734 (83\%) are cross-cited articles.

\begin{tabular}{|c|c|c|c|c|c|c|}
\hline \multirow[b]{2}{*}{ Papers } & \multicolumn{2}{|c|}{ Gross sample } & \multicolumn{2}{|c|}{ Outliers } & \multicolumn{2}{|c|}{ Net sample } \\
\hline & \# & $\%$ & $\#$ & $\%$ & \# & $\%$ \\
\hline Gross sample & 1,155 & $100 \%$ & 268 & $23 \%$ & 887 & $77 \%$ \\
\hline Disconnected papers & 394 & $34 \%$ & 241 & $90 \%$ & 153 & $17 \%$ \\
\hline Connected papers & 761 & $66 \%$ & 27 & $10 \%$ & 734 & $83 \%$ \\
\hline Total & 1,155 & $100 \%$ & 268 & $100 \%$ & 887 & $100 \%$ \\
\hline
\end{tabular}




\subsection{Network and cluster analysis}

When studying the scientific production within a field, we are interested in examining two main issues: i) the identification of the temporal patterns, and ii) how different topics are discussed within the literature. To deal with the latter matter, which is the main objective of this paper, we need to cluster the literature in order to detect similar subjects within differing groups. The clustering of documents can be achieved by using a number of techniques that require traditionally, some classification and categorization. Then, several methods can be used for grouping the papers in clusters based on the statistical similarity of their salient characteristics (Baggio and Klobas, 2017).

A more efficient and effective alternative is to resort to the methods of network science. The basic idea is that: a paper cites other works that mostly fall in the same (or similar) domain. The citations, or better the cross-citations, represent links between papers and this naturally leads to the formation of a network in which the nodes are the papers and the links represent the bibliographic references.

This technique (citation network analysis) has a long tradition and has proved to be an effective tool to analyse the structure of scientific research, and to depict different domains to uncover emerging research strands in many disciplines, including tourism (Benckendorff and Zehrer, 2013; Cardillo et al., 2006; Newman, 2004; Ye et al., 2013).

Once the network has been assembled, a number of different metrics can be used to characterize the main structural properties (da Fontoura Costa et al., 2007). Among the most important are: the number of links each node has (degree) and the statistical distribution of the degrees, the density (number of links existing as a fraction of the maximum possible number of links), the average path length (average distance between any two nodes). This global topological analysis, however, concentrates on the average properties of the network and can miss the important and interesting features that may exist inside. These can be unveiled by clustering the nodes and investigating this clustering to infer additional insights about the mesoscopic structure of the original network. The approach works on the possibility to recognize the internal structure of the network by identifying groups of nodes (papers) that are more densely connected between themselves than to other nodes in the network, these are called modules, clusters or communities.

In this study, clusters when correctly identified, correspond to groups of works with similar topics, since being more connected means higher number of cross-citations and hence a higher similarity in the issues discussed by the papers. The extent to which a network has a modular structure is measured by the metric Q. This measures the strength of division of a network into different modules, and is calculated as the fraction of the edges that fall within the given groups minus the expected fraction if edges were distributed at random. The higher the Q value, the more defined and separated the modules found (actually Q is normalized, so $0=$ no modular structure, $1=$ completely separated modules). Figure 1 points out, as an example, a network with four (well separated) communities and $\mathrm{Q}=0.75$. 
Figure 1. A modular network with four communities and $Q=0.75$

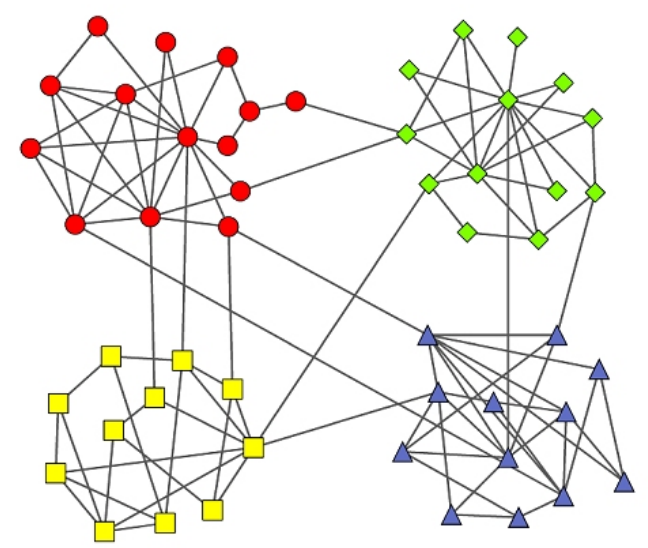

Several stochastic algorithms exist for computing the modularity of a network and detecting the different communities. They differentiate themselves in terms of the network characteristics they consider (directionality, weights, etc.) and the resolution power, that is the capacity to detect the fine structure of the network under study (Fortunato, 2010). Here we use the so-called Louvain algorithm proposed by Blondel et al. (2008). This is a fast procedure able to return high quality outcomes. It is a heuristic iterative algorithm made of two steps that are repeated iteratively. It starts by randomly assigning each node to a community. Then each node is moved to a neighbour's community and the algorithm calculates the variation in the modularity metric Q. The node is assigned to the community that produces the largest positive increase of Q. In the second step, each community is replaced by a "super node" and the resulting clustered network undergoes the same procedure. The two steps are repeated until no more variations in modularity are attained. By tuning a resolution parameter, the Louvain method allows the detection of communities at different scales. Here we use a value of 1 that provides a good resolution power allowing the discovery of reasonably sized and separated clusters. The community analysis is applied to the largest connected component of the network.

These calculations found 14 clusters with a modularity index $\mathrm{Q}=0.65$, that implies a well clustered network. These communities were then further analysed with the same algorithm, thus highlighting groups of similar papers within the different clusters. A closer (qualitative) inspection of these groups allowed the classification of further topics. These are examined and discussed in next section.

\section{Findings}

Results of the study are now explored within the contexts of the two research questions. A full descriptive analysis of papers included in the network is given in Section (4.1). The following section paragraph (Section 4.2) depicts the main topics developed in each cluster, in order to identify the salient sub-fields of the hotel performance research stream.

\subsection{RQ 1: Trends and network description}

This first paragraph focuses on papers that are "connected" within the network. Of 1,155 contributes, 761 are connected studies. By contrast, 34\% of sample (394 papers) consists of "unconnected" works, that are not considered in the findings section. A descriptive analysis is now given, depicting the year of publication (time) and some journal information. 
Table 2. Time

\begin{tabular}{|c|c|c|c|c|c|c|}
\hline Time & Papers (\#) & Papers (\%) & Journals (\#) & Papers per journal & Number of citations & Citations per paper \\
\hline $96-00$ & 32 & $4 \%$ & 17 & 1.9 & 792 & 24.8 \\
\hline 01-05 & 72 & $10 \%$ & 28 & 2.6 & 2,414 & 33.5 \\
\hline $06-10$ & 221 & $30 \%$ & 71 & 3.1 & 4,740 & 21.4 \\
\hline $11-15$ & 409 & $56 \%$ & 111 & 3.7 & 2,290 & 5.6 \\
\hline Total & 734 & $100 \%$ & 164 & 4.5 & 10,236 & 13.9 \\
\hline
\end{tabular}

Time

More than half (56\%) of the connected papers belong to the fourth-time period (2011-2015), while only $15 \%$ of them are published between 1996-2005 (Table 2). The data depicts a clear acceleration in the publication trend of hotel performance, confirming observations of previous studies (e.g. Sainaghi et al., 2017). Interestingly, the number of journals display a parallel increase: in the first-time period 17 journals were found, while in the last time period 111. This suggests the importance of including samples with non-leading and non-top scoring tourism and hospitality journals (Gursoy and Sandstrom, 2016). During the period of the review, the average number of papers published per journal show a progressive increase, moving from 1.9 ( $1^{\text {st }}$ time period) to 3.7 ( $4^{\text {th }}$ time period $)$. By contrast, the number of citations and in particular the citations per paper (last column) depict a decreasing trend. This is not a new observation in review studies, given the time delay between publication and citations. As usual, older papers attract higher average number of citations compared to newer contributes. Table 2 confirms this trend: papers belonging to the $2^{\text {nd }}$ time period attracts the highest citations per paper (33.5), while the $4^{\text {th }}$ time period the lowest (5.6).

Table 3. Top ten journals (based on number of papers)

\begin{tabular}{|c|c|c|c|c|c|c|}
\hline Journals & $\begin{array}{l}\text { Papers } \\
\text { (\#) }\end{array}$ & $\begin{array}{c}\text { Papers } \\
\text { (\%) }\end{array}$ & $\begin{array}{c}\text { Journals } \\
\text { (\#) }\end{array}$ & $\begin{array}{c}\text { Papers } \\
\text { per } \\
\text { journal }\end{array}$ & $\begin{array}{c}\text { Number } \\
\text { of } \\
\text { citations }\end{array}$ & $\begin{array}{c}\text { Citations } \\
\text { per } \\
\text { paper }\end{array}$ \\
\hline International Journal of Hospitality Management & 142 & $19 \%$ & 1 & 142.00 & 2,651 & 18.7 \\
\hline International Journal of Contemporary Hospitality Management & 79 & $11 \%$ & 1 & 79.00 & 817 & 10.3 \\
\hline Tourism Management & 43 & $6 \%$ & 1 & 43.00 & 1,496 & 34.8 \\
\hline Service Industries Journal & 32 & $4 \%$ & 1 & 32.00 & 492 & 15.4 \\
\hline Cornell Hospitality Quarterly & 32 & $4 \%$ & 1 & 32.00 & 312 & 9.8 \\
\hline Journal of Hospitality and Tourism Research & 31 & $4 \%$ & 1 & 31.00 & 349 & 11.3 \\
\hline Tourism Economics & 22 & $3 \%$ & 1 & 22.00 & 220 & 10.0 \\
\hline Asia Pacific Journal of Tourism Research & 13 & $2 \%$ & 1 & 13.00 & 42 & 3.2 \\
\hline Journal of Hospitality Marketing and Management & 11 & $1 \%$ & 1 & 11.00 & 90 & 8.2 \\
\hline Cornell Hotel and Restaurant Administration Quarterly & 10 & $1 \%$ & 1 & 10.00 & 230 & 23.0 \\
\hline Total Top Ten & 415 & $57 \%$ & 10 & 41.50 & 6,699 & 16.1 \\
\hline Others & 319 & $43 \%$ & 154 & 2.07 & 3,537 & 11.1 \\
\hline Total & 734 & $100 \%$ & 164 & 4.48 & 10,236 & 13.9 \\
\hline
\end{tabular}

Top ten journals

Top ten journals are defined, in accordance to the work of Sainaghi et al. (2017) as the journals that account for the highest number of papers. Table 3 reports these details and ranks the journals according to the number of published papers (first column). Given the focal point on the hotel sector, the first two journals are focused on hospitality (International Journal of Hospitality Management, and International Journal of Contemporary Hospitality Management) representing 30\% of connected papers (221). Generally speaking, top ten journals account for the majority of total connected papers $(57 \%)$, but, more importantly, a majority of citations $(6,699,65 \%)$. The average number of citations per paper is 16.1 for top 
ten, which is $16 \%$ higher than general mean (13.9). Other journals show 11.1 citations per paper, which is $20 \%$ below. Tourism Management, despite its main but not exclusive focus on tourism, is the first journal in the list in term of citations per paper (34.8, a value more than double compared to the mean).

Table 4. Leading and non-leading journals

\begin{tabular}{lcrrrrr}
\hline Journals & $\begin{array}{c}\text { Papers } \\
\text { (\#) }\end{array}$ & \multicolumn{1}{c}{$\begin{array}{c}\text { Papers } \\
\text { (\%) }\end{array}$} & $\begin{array}{c}\text { Journals } \\
\text { (\#) }\end{array}$ & $\begin{array}{r}\text { Papers } \\
\text { per } \\
\text { journal }\end{array}$ & $\begin{array}{c}\text { Number } \\
\text { of } \\
\text { citations }\end{array}$ & $\begin{array}{c}\text { Citations } \\
\text { per } \\
\text { paper }\end{array}$ \\
\hline Leading & 345 & $47 \%$ & 8 & 43.1 & 5,949 & 17.2 \\
Non-leading & 389 & $53 \%$ & 156 & 2.5 & 4,287 & 11.0 \\
\hline Total & $\mathbf{7 3 4}$ & $\mathbf{1 0 0 \%}$ & $\mathbf{1 6 4}$ & $\mathbf{4 . 5}$ & $\mathbf{1 0 , 2 3 6}$ & $\mathbf{1 3 . 9}$ \\
\hline \hline
\end{tabular}

\section{Leading journals}

Leading journals are defined according to Sainaghi et al. (2013) segmentation. Leading tourism and hospitality journals (ordered according to the number of papers) include: International Journal of Hospitality Management, International Journal of Contemporary Hospitality Management, Journal of Hospitality and Tourism Research, Tourism Management, Cornell Hospitality Quarterly, Cornell Hotel and Restaurant Administration Quarterly, Journal of Travel Research, and Annals of Tourism Research. Table 4 shows the relevance of leading journals in terms of published papers $(47 \%)$, number of papers per journal (43.1 compared to a general mean of 4.5) and citations per paper (17.2). By contrast, non-leading journals are also relevant, considering that $53 \%$ of connected papers were published in these journals, and able to attract 4,287 citations (42\%). This analysis confirms the importance of including non-leading journals in the sample selection. From a researcher point of view, a leading journal is able to assure a significant higher number of citations per paper (17.2) than a non-leading journal (11.0); the first value is $56 \%$ higher than the second one.

Table 5. Top scoring journals - based on Gursoy and Sandstrom (2016)

\begin{tabular}{lrrrrrr}
\hline \multicolumn{1}{c}{ Journals } & $\begin{array}{c}\text { Papers } \\
\text { (\#) }\end{array}$ & \multicolumn{1}{c}{$\begin{array}{c}\text { Papers } \\
\text { (\%) }\end{array}$} & $\begin{array}{r}\text { Journals } \\
\text { (\#) }\end{array}$ & $\begin{array}{c}\text { Papers } \\
\text { pournal }\end{array}$ & $\begin{array}{c}\text { Number } \\
\text { of } \\
\text { citations }\end{array}$ & $\begin{array}{c}\text { Citations } \\
\text { per } \\
\text { paper }\end{array}$ \\
\hline $\begin{array}{l}\text { Top scoring tourism and } \\
\text { hospitality journals }\end{array}$ & 405 & $55 \%$ & 16 & 25.3 & 6,449 & 15.9 \\
Non-top scoring & 329 & $45 \%$ & 148 & 2.2 & 3,787 & 11.5 \\
\hline Total & $\mathbf{7 3 4}$ & $\mathbf{1 0 0 \%}$ & $\mathbf{1 6 4}$ & $\mathbf{4 . 5}$ & $\mathbf{1 0 , 2 3 6}$ & $\mathbf{1 3 . 9}$ \\
\hline
\end{tabular}

Focus on Gursoy and Sandstrom (2016) top scoring tourism and hospitality journals

The distinction between top scoring tourism and hospitality journals, on one hand, and nontop, on the other, is based on the work of Gursoy and Sandstrom (2016). In their review, there are 18 top scoring tourism (10) and hospitality (8) journals; our sample includes 16 of these journals. As reported in Table 5, 45\% of connected papers are generated by non-top scoring journals. The top scoring tourism and hospitality field, by contrast, attracts the highest number $(55 \%)$ of papers, the highest value of papers per journal (25.3) and citations per article (15.9). It is interesting to note that non-top scoring journals account for 148 journals, 
with an average of 2.2 articles per journal. The gap in term of citations per paper is relevant: top scoring papers account for 15.9, while non-top scoring 11.5; the first value being $38 \%$ higher than the latter.

\subsection{RQ 2: Clusters}

This section focuses on the second research question and presents topics identified in the clusters. The network cluster analysis identified 14 groups, that are presented starting from the smallest to the highest. Given the high number of articles, references are not reported in the bibliography. The full list of articles is available on request. For each cluster, the following issues are analysed: i) general topic, ii) main underlying discipline, iii) number of papers, iv) relationship with performance, v) sub-topics, and vi) performance indicators. Figure 2 reports the whole network (left-side) and, as an example, the four broadest clusters $(11,12,13$ and 14) are represented, revealing some sub-clusters (as later presented and discussed).

Figure 2. The papers' network and the main clusters.

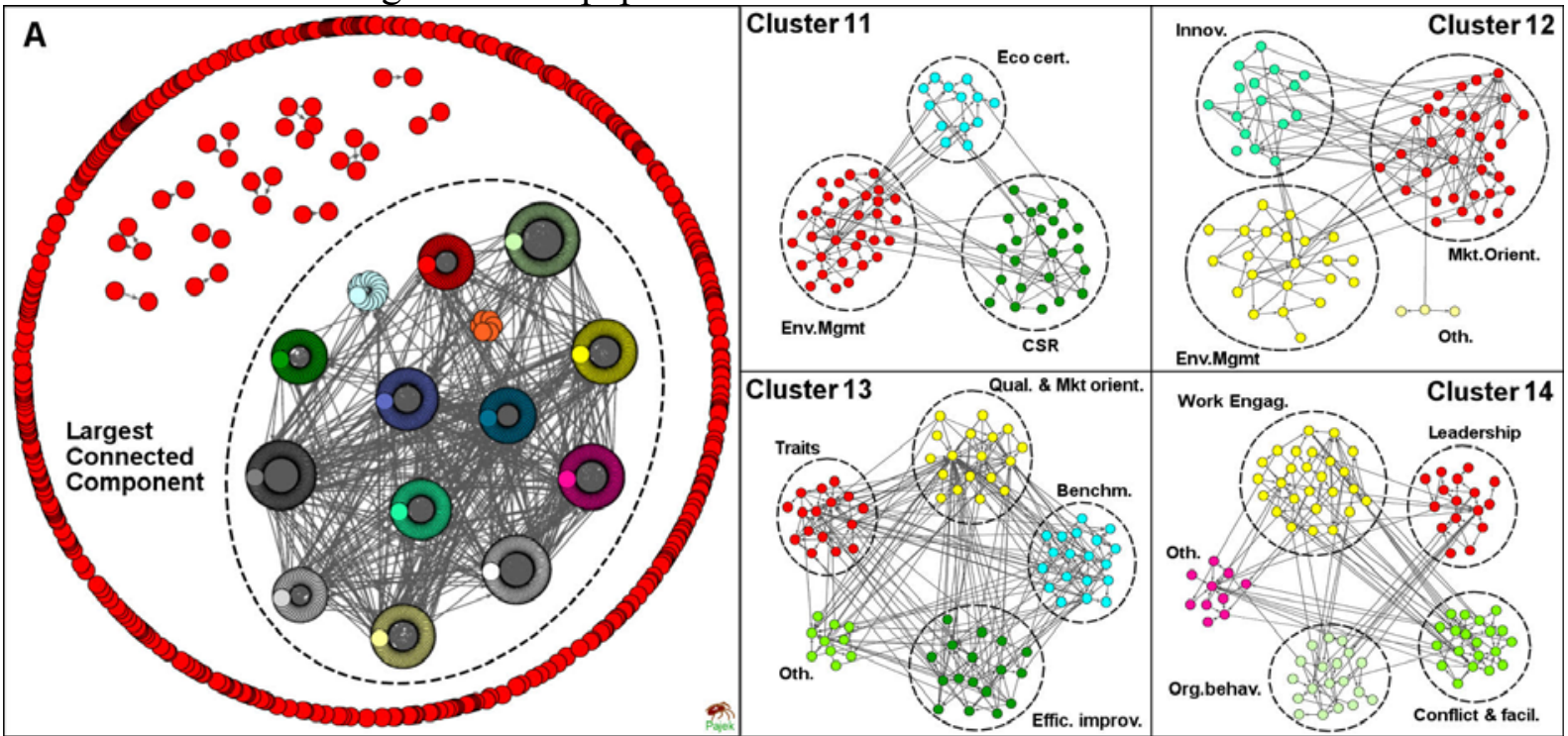

Legend: Panel A contains the whole network where the largest connected components split into clusters. As an example, the four largest clusters $(11,12,13$ and 14) are shown here with their different components (see text for their meanings and characteristics).

\section{Cluster 1 -Qualitative studies on Human Resource Management}

This group consist of six papers with the prevalent topic being Human Resource Management (HRM). It is important to note that HRM is the main topic of another large cluster (14), composed by 91 papers. So, why do these six papers create a separate cluster? A possible answer is related to the different journals and topics/methodology used by cluster 1 . Concerning the journals, all these outputs are published in non-top ten, non-leading, and nontop scoring (Gursoy and Sandstrom) journals. Probably this cluster is distanced in terms of the proximity of relationships with papers belonging to cluster 14. Furthermore, inside this cluster, the methodology is primarily based on case studies and qualitative explorative mixed method approaches.

The topics explored are mainly related to job motivation and satisfaction that "has been associated with positive organizational outcomes such as increased employee productivity, higher innovation and reduced turnover, all of which are linked to improved firm performance" (Sledge et al., 2008). Motivation is considered to be a primary determinant of 
job satisfaction (Chen and Wang, 2015). Papers explore some analytical themes, such as the link between culture and motivation, the effects generated by the inclusion of foreign seasonal workers in the staff on motivation, the relevance of diversity or the enlargement of roles (Sizoo et al., 2005).

Given the prevalent qualitative approach, the relationship with hotel performance is more hypothesised than explored. As previously stated, the basic hypothesis of this seam of research is the ability of motivated employees to increase competitive indicators (occupancy, sales, average daily rate) or process performance (employee productivity).

\section{Cluster 2 - External determinants}

This group comprises of 12 papers; the topic of cluster 2 is termed external determinants of hotel performance and the independent variables are mainly represented by macroeconomic antecedents. In terms of discipline, this cluster is related to finance. In coherence with this approach, the dependent variable is usually financial performance, mainly operationalized using indices related to stock market return and risk. Focusing on these topics, this cluster depicts three themes: i) monetary policy or other macro-economic variables, such as consumer confidence, ii) business cycle and corporate governance, and iii) crisis and external shocks. Before analysing the sub-topics, it is important to note that Chen, with 9 papers out of 12 , is the prominent author.

Monetary policy includes five papers primarily focused on the effects generated by liquidity crisis. These contributes compare different monetary policy environments, as expansive and restrictive or the variation of interest rate (Dewally et al., 2013). In the sub-stream of business cycle and corporate governance, papers explore the effects generated by some National strategies (as the government weekend policy changes in Taiwan), business cycle or corporate governance (Chen et al., 2009). Concerning crisis and external shocks, research analysis include the effects generated by variation in gross domestic product or by international shocks, such as the 9/21 earthquake in Taiwan, the 9/11 terrorist attacks in the US, or the SARS outbreak (Chen, 2015).

As previously stated, performance indicators are mainly financial indicators (stock return, risk, Sharpe ratio, Treynor's measure, and Jensen's alpha) integrated with accounting measures (financial ratios) and competitive indicators (average daily rate, occupancy and revenue per available room (RevPAR)).

\section{Cluster 3 - Internal operational and soft determinants of hotel performance}

This group consists of 40 papers. The basic topic of this cluster is internal operational and soft determinants of hotel performance. The dependent variable is mainly represented by business performance, which is a broad concept usually including both operational and financial measures. Independent variables belong to five different groups: i) performance measurement systems, ii) information technology, iii) relational capabilities, iv) intellectual capital and v) competitive strategy. The scope of these issues within this cluster make it difficult to identify a single discipline, although strategic management plays a central role, representing the field of performance measurement systems, capabilities, intellectual capital and competitive strategy. The unifying characteristic is more related to the use of "soft" and "internal" determinants.

The first research stream explores some indices of performance. These papers propose key performance indicators; they identify critical success factors or formulate some relevant indices (Avcikurt et al., 2011). The core of the second sub-group is information technology and explores the link with performance within upscale hotels, the acceptance of technology and the ability of firms to realize a business-information technology alignment (Charoensuk et al., 2014). The development of relational capabilities is at the kernel of a third group of 
papers, that explores different drivers such as relationships with clients - customer relationship management and relationships with revenue management and marketing - and other firm's stakeholders, such as competitors (Casanueva et al., 2015). This subfield suggests the relevance of different kind of capabilities - as resource mobilization capability (Sainaghi and De Carlo, 2016), marketing alliances capabilities, entrepreneurship capabilities - and the role of social capital. Intellectual capital is used as an independent variable in some studies exploring the link with business performance in different geographical settings, mainly represented by Europe and Middle East locations and in upper-upscale hotels (Bontis et al., 2015). The last sub-group is related to competitive strategy and is centred on Sharma's work (i.e. Sharma and Christie, 2010).

Finally, concerning performance indicators this cluster is consistent with the wider issues explored and proposes many different measures. Papers focused on marketing (customer relationship management) use more financial and operational indices (sales growth, and market share). Research routed in information technology depict both financial indicators and process performance principally related to productivity and flexibility. The remaining three groups are more related to strategic management (competitive strategy, intellectual capital and relational capabilities) displaying a stronger link with financial measures (gross operating profit, and financial indices).

\section{Cluster 4 - Diversification strategies}

Cluster 4 includes 41 papers. The cluster deals with market and product diversification, on one side, together with some processes linked to diversification: i) performance measurement systems, using some typical hospitality indices (sales measures) and financial indices (risk and stock return), ii) diversification strategy, iii) HRM, iv) organizational competencies, and v) technology. Dependent variables are mainly represented by business performance; this appears reasonable, considering that diversification generates effects on both operational and financial performance. The main discipline of this cluster is management, and in particular strategic management (diversification and competencies).

The largest group focuses on performance measurement systems. Two different approaches are proposed: on one side, there is criticism about traditional performance indicators and in particular versus RevPAR, while some articles focus on revenue management (Chen et al., 2011). A second, broader group, propose financial indicators, mostly based on risk-return or stock performance or both (Giannotti et al., 2011). The relevance of these measures appears coherent with the general topic of this cluster, related to diversification.

The second group develops diversification strategies, exploring revenue diversification (F\&B and room), sector differentiation (full-service, economy, and fast-food restaurants), product differentiation, segment diversification, corporate governance diversification, or market diversification (Chen and Chang, 2012). In order to achieve this diversification, this cluster includes three processes that can be activated. A first driver is represented by HRM practices, analysing the effect generated by different organizational structures, alternative forms of control, or styles able to reduce burnout, and to increase commitment and corporate entrepreneurship (Campopiano et al., 2016). The development of competencies being the second driver; some articles explore some relevant functions, such as marketing or key stakeholders, including customers, employees, or partners in business ( $\mathrm{Ku}, 2014)$. The last driver is represented by technology, exploring mainly the acceptance of it by clients and employees (Kaushik et al., 2015).

This cluster applies a wide spectrum of performance indicators. Concerning performance measurement systems, papers are relatively old. The mean year is 2008 , while the average value of all the sample is 2010. Therefore, it is unsurprising that this sub-topic suggests the need for distinction between financial and non-financial indicators. Furthermore, as 
previously stated, some papers claim the "unreliability" of RevPAR and the need to include non-room revenues. This point is particular pertinent especially for diversified hotels (e.g. casinos) that have relevant ancillary services. Articles belonging to diversification strategy used financial indices (operating margins and ratios) more intensively, sometimes integrated with stock measures (as risk-adjusted performance and capitalization), and usually integrated with some competitive results (occupancy, average daily rate, and RevPAR). Finally, the three "technical" sub-groups are very small and therefore it is difficult to identify recurring performance indicators. Generally speaking, they tend to use process indicators such as job satisfaction, technology acceptance or team performance (for relational capabilities).

\section{Cluster 5 - HRM as antecedents of hotel performance}

Despite the fact cluster 5 includes 44 papers, it appears homogeneous both in terms of dependent and independent variables. Dependent variables are mainly represented by business performance, operational performance and process performance, using indicators relating to HRM, such as job performance. The independent variables are principally related to: i) HRM practices (the largest group, that accounts for more than 50\%), ii) agglomeration and geographical competition, plus some and iii) other marginal themes, such as service quality and corporate governance. Given the centrality of papers focused on HRM, this is the prominent discipline of this cluster.

Focusing the attention on HRM contributions, papers generally use HRM as antecedents of hotel performance and can be divided in four approaches. A first group uses job performance as a dependent variable, operationalised in term of staff turnover or high-performance employees (Ahmad and Scott, 2014). A second basket of papers explore the relationship between HRM and service quality and customer satisfaction (Lee et al., 2015). Another subresearch stream explores the link between HRM and hotel performance, operationalized using business performance, including both operational and financial indicators. These contributes usually employ HRM as antecedents, or some processes such as training, and gender differences (Ubeda-García et al., 2013). Finally, a fourth group employs HRM as determinants of business performance (like the third one) but adding some control variables primarily based on strategy.

A second research stream within the cluster explores the link between agglomeration and geographical competition and hotel performance. Results are usually measured using operational performance, typically price, occupancy, and RevPAR (Chung and Kalnins, 2001). Some papers deal in detail about agglomeration strategies, understanding the effect for undifferentiated hotels or the link with performance (Lee and Jang, 2015). Other works study some related topics, such as the effect of new entrants on hotel results, the impact of bed taxes on competition, the role of competitive sets or the agglomeration effect generated by tourist districts and territories The link between the HRM papers and the small group of agglomerations is again created by the work of Chung and Kalnins (2001), cited by Chand (2010) - HRM and service quality and customer satisfaction - and by Chand and Katou (2007) - HRM and job performance. These two outputs are core in their respective groups. Finally, other papers are mainly focused on corporate governance, exploring the link with performance using stochastic frontier analysis and measuring hotel efficiency (Jarboui et al., 2015). The relationship between this research stream (corporate governance) and the whole cluster (HRM) can be noted at least in two aspects: both explore antecedents of hotel performance, the contributions relating to corporate governance discuss the effects of compensation practices (Jarboui et al., 2015). This corporate governance topic is clearly related with HRM practices. 


\section{Cluster 6-Competitive strategy}

This cluster accounts for 45 papers. The predominant topic is strongly related to competitive strategy with four sub-groups: i) competitive strategy (the largest group), ii) sales performance determinants, iii) outsourcing strategy, and iv) strategic practices and benchmarking. The underlying discipline is management and in particular strategic management.

The central group of competitive strategies reflects the Porterian approach, distinguishing between external and internal factors. Some papers analyse industry attractiveness and they are mainly focused on the industrial organization (IO) paradigm, using strategic groups (Pine and Phillips, 2005) or exploring the relevance of local context, such as tourism destination (d'Angella et al., 2010; Sainaghi, 2006, 2010c; Sainaghi and Canali, 2011) or sector scanning (Sund, 2013). Internal strategy (competitive strategy) is analysed employing different determinants: business and competitive strategy, accounting management, corporate governance choices, technology, marketing strategy, and market orientation. A second subgroup of papers focuses on sales performance determinants and, in particular, on price determinants. In this field, there are some works related to occupancy, that analyse the effect of seasonality and social capital, considering the "complexity" of tourism destinations (Baggio and Sainaghi, 2011); other studies explore price determinants, such as hotel traits (Sainaghi, 2011). A third sub-field is cantered on outsourcing and explore some determinants of outsourcing, such as IT, accounting system, and asset specificity (De Vita and Tekaya, 2015). A fourth sub-group proposes benchmarking and managing practices in the field of strategic management, strategic behaviours, hotel positioning, hotel traits or best practices to maximize profit and room price (Lee, 2011).

Finally, performance indicators, coherently with the prominent discipline, are mainly related to competitive indicators (average daily rate, RevPAR, occupancy, and revenues). This is particularly evident for papers routed in sales performance, benchmarking and accounting measures (financial margins and ratios). Other papers use stock market indicators or efficiency measures (e.g. productivity). Papers centred on outsourcing include some additional non-financial indicators that are more focused on operating processes, as they seek improvement in quality, flexibility, and adaptability. These indices are usually measured subjectively, using questionnaires.

\section{Cluster 7 - Performance measurement systems}

This cluster consists of 55 papers; the general topic being performance indicators or performance measurement systems. Three main sub-groups were identified: i) non-accounting measures, ii) BSC approach, and iii) accounting indices. The main discipline of this cluster is accounting. This cluster accounts for the highest percentage of top ten papers and also one of the highest percentages in terms of leading and top-scoring journals. Performance measurement systems play a vital role for companies and hotel managers.

A first and broader group is primarily focused on non-financial performance indicators, suggesting their relevance in many hotels, normally mixed with financial or accounting indices. The proposed indicators are related to different hotels functions, such as sales, with concentration in revenue management, market orientation, marketing performance, customer relationship management, benefits and costs of frequent-guest programs, and sales indicators. Some works focus on operations, intangible resources, maintenance, facilities and facility management. Others explore the use of "old" and "new" performance measurement techniques in a joint venture. Phillips (1999) proposes a performance measurement system that includes input and output processes.

A second group explores the role of the $B S C$ to measure and evaluate hotel performance. At the hub of this group is the review of Sainaghi et al. (2013), with other papers being mainly 
empirical. The BSC has been advocated as an implementation tool, with some studies highlighting strategic control. Inside this research stream, there are some papers proposing key performance indicators or suggesting the importance of designing strategic performance measurement systems, including the customer perspective.

The third sub-group includes articles routed in the accounting approach. It is a small group mostly centered on the Mia (and Patiar) work, and focused on accounting performance indicators. Six articles were published between 2001 and 2009, topics range from management accounting systems (Patiar and Mia, 2008), budget participation (Mia and Patiar, 2002), and information technology and budget participation (Winata and Mia, 2005).

Each sub-topic shows a clear link with some performance indicators: accounting is mainly based on financial measures (operating margins and financial ratios) and competitive results (average daily rate, occupancy, and RevPAR). Similarly, the performance measures used by papers based on the BSC approach, incorporate both stock performance indicators (value and risk) and customer satisfaction. Finally, non-accounting articles propose some "new" indices mainly focused on specific stakeholders, such as customers and employees. Customer indices are prevalent and are designed in some typical selling processes. For example, McManus (2013) proposes 11 indicators, mixing accounting measures (chiefly costs and revenues) and some marketing processes (e.g. customer satisfaction, acquisition, and loyalty). These new perspectives are usually integrated with traditional accounting measures (both financial and competitive indicators).

\section{Cluster 8 - Social media}

Cluster 8 includes 56 papers; the topic of this cluster is social media and comprises four subgroups: i) social media and online reviews, ii) websites, iii) market orientation, and iv) environmental management. The dependent variable is usually represented by operational performance. The discipline of this cluster is marketing.

The first and the main distinctive sub-group of this cluster analysis is social media and online reviews. Concerning the first topic, some studies describe social media management of a few destinations, depict best practice or propose performance indicators, such as effectiveness measures; other papers explore the relationship between online reviews and sales, or use reviews such as determinants of operational performance (Torres et al., 2015). They can help to identify important hotel attributes for customers, that impact positively on word-of-mouth and online sales. Online reviews are used as a proxy of resource capability and they are linked to customer satisfaction.

The second sub-group analyses websites. This body of work propose performance indicators for websites: Chung and Law (2003) develop and build indicators around five dimensions: Maier (2012) measure websites effectiveness; Yeung and Law (2004) propose a usability index. Few studies explore the outcome of website management; Panagopoulos et al. (2011) develop a comprehensive evaluation framework based on some key stakeholders' judgments. Empirical evidence suggests a positive effect upon RevPAR. Finally, the majority of studies explore the diffusion of website technology in some destinations. Empirical findings suggest that hotels are more skilled in website management with some recurrent traits: being large, high-quality, and mainly located in attractive destinations. Some studies consider the specific responses to website customer queries, finding that many hotels missed the opportunity to increase sales by failing to respond adequately to electronic reservation enquiries.

There are some papers largely focused on market orientation or, more generally, on sales strategy, online reviews and e-word of mouth. This third sub-stream is coherent to the cluster approach, which analyses relationships with clients managed using social media. Some studies explore the link between market orientation and corporate social responsibility $(\mathrm{Qu}$, 2009). 
Within this cluster there is an important basket of papers focused on environmental management. Apparently this fourth topic appears to be completely disconnected from social media. In reality, this is an intriguing, as social media creates relationships with customers, so environmental papers recognize an increasing sense of awareness of customers for sustainability. In this research stream, papers explore water consumption, carbon footprint, land use, energy saving, and eco-resorts (Huang et al., 2015).

Performance indicators are considerably different for each sub-topic. As previously stated, social media and online reviews use more competitive indicators, mainly represented by average daily rate (ADR), RevPAR, market share, revenues or some indices related to customer satisfaction and retention. In the case of websites, papers propose some technical indicators especially focused on measuring the website performance and in particular their usability and effectiveness. Market orientation operationalizes performance using both competitive indicators (market share, and sales growth), financial indicators (operating margins and financial ratios) and mostly customer satisfaction. Finally, environmental management contributes use operating process indicators such as water consumption, energy saving, land use, and gas emission.

\section{Cluster 9 - Marketing and brand management}

With 59 papers, the central theme of this cluster is brand management and three sub-groups were identified: i) brand management, ii) pricing, and iii) marketing strategies and crisis management. Given the focus on selling processes, unsurprisingly the dependent variables are mainly related to "operational performance", usually represented by ADR, occupancy and RevPAR, or customer satisfaction. The prominent discipline is marketing.

Brand management is the top group and is predominantly used in many papers as antecedents of hotel performance, where performance is measured by operational performance, including pricing (Wang \& Chung, 2015). Other studies explore the antecedents of brand, using four main components of brand-equity: brand awareness, brand loyalty, perceived quality and brand image (Kayaman and Arasli, 2007). Further works explore the relationships among brand and customer satisfaction, marketing, quality management and the employee. This last topic is further developed in some studies by focusing on internal branding, exploring mechanisms and outcomes or researching the relationships with employee commitment and delivery (Yang et al., 2015). Branding can reduce risk in service businesses, and branded hotels tend to achieve better net operating income than unbranded firms during economic recessions (O’Neill and Carlbäck, 2011).

Moving from branding to pricing, papers focus on competitive pricing and particularly during uncertain times, in areas such as discounting policies, strategic price positioning, the influence of technology on room-rate, and the influence of advertising on price elasticity (Chen et al., 2015). Other studies focus on revenue management (RM), such as the scope of RM, the future of this function, the link with operational performance, or propose models to measure tourist expenditure (i.e. Sainaghi, 2012).

Finally, the third sub-group (the smallest one) is focused on marketing and crisis management, and the exploration and use of marketing strategies during uncertain times, such as the BP oil crisis, 9/11, financial crisis, or inflationary periods (Alonso-Almeida and Bremser, 2013).

Concerning indicators, papers focused on branding sometimes propose brand measures, mainly operationalized around competitive performance as customer satisfaction, return intent, and price-value perception. Articles within this sub-topic usually adopt selling measures as ADR, occupancy and RevPAR. Financial measures are rarely used and when applied are normally measured subjectively. The sub-stream of price are mainly financial and accounting measures, as operating margins and profitability. Finally, marketing and crisis 
management operationalizes performance principally in terms of competitive (ADR, occupancy and RevPAR) and financial indicators (gross operating profit, net income, and financial ratios).

\section{Cluster 10 - Customer satisfaction and service quality}

This cluster includes 62 papers and develops two interrelated topics: i) customer satisfaction and ii) service quality. These two sub-groups are interrelated, since the ability of service quality of improving customer satisfaction. Marketing is the main discipline. This basket of papers usually use customer satisfaction as a dependent variable; financial and competitive measures are more rarely used.

Customer satisfaction accounts for the highest percentage and it is the most frequently used dependent variable, followed by the measurement of service quality and the use of operational and financial performance. As an independent variable, papers on customer satisfaction can be categorized into three approaches: works focused on antecedents, outcomes, and methodology. Service attributes and hotel traits are the main antecedents of customer satisfaction. However, studies consider different countries, quality levels, hotel departments, tourist products, segments, and preferences; for this reason determinants are numerous and distinct (Mohsin and Lengler, 2015). A second group of papers use customer satisfaction as an outcome and these works explore the link with hotel performance (operational or financial results). It is a small subfield and in some cases customer satisfaction is used alone or in combination with other internal variables, such as HRM and service quality (Assaf et al., 2015). A third group proposes different methods in order to identify key determinants of customer performance. These studies usually apply importance-performance approach (IPA) or some variants, such as asymmetric IPA (AIPA) (Albayrak and Caber, 2015).

The second important sub-research stream is service quality. Outputs can be divided into two groups, antecedents and methods. Studies exploring determinants of service quality suggest the relevance of service quality (SERQUAL) approach, with some adaptation to the hospitality sector; more recent papers explore new determinants: HRM, physical and mental tangibility, and contract law approaches (Serrat, 2011). Research methods focus on IPA, but with many adjustments, considering: fuzzy approach (FIPA), competitors (IPCA), zone of tolerance and competitors (CZIPA) (Albayrak, 2015).

This cluster, as previously noted, operationalizes performance especially using process indicators related to customer satisfaction or, more rarely, to customer loyalty and switching intention. The components of customer satisfaction are broad and include facilities, price, room and front desk service, service quality, security, location, staff, and meals. Generally speaking, customer satisfaction is measured subjectively using questionnaires or social media. Customer satisfaction is the typical dependent variables and also for studies pertaining to the service quality research stream.

\section{Cluster 11 - Environmental management and corporate social responsibility}

Cluster 11 includes 68 papers with focus on i) environmental management (EM), ii) corporate social responsibility and iii) eco-certification. Unsurprisingly, the Journal of Sustainable Tourism is the second most popular journal in terms of the number of published papers. The underlying topic is represented by "sustainability", which can be broken down into environmental or eco-sustainability, on one side, and social or stakeholder sustainability, on the other.

Environmental management "involves the study of all technical and organizational activities aimed at reducing the environmental impact caused by a company's business operations [...]. Proactive environmental management can be understood to be a systematic pattern of voluntary practices that go beyond regulatory requirements" (Pereira-Moliner et al., 2015, p. 
716). This first broad sub-group includes many different studies under the umbrella of environmental management and explores the role of environmental management as a source of competitive advantage, innovation, and sustainability (Tugores and García, 2015).

The second sub-topic is represented by corporate social responsibility. Papers are mainly oriented to explore the link between corporate social responsibility and hotel performance, including various moderating factors, such as ethical leadership (Zhu et al., 2014). Other articles consider the ability of internal stakeholders to develop and implement corporate social responsibility practices (Paek et al., 2013). Further studies report practices adopted by the largest hotel companies and explore the highest performing corporate social responsibility initiative, mainly represented by popular environmental practices focused on energy, waste and water management (Tang et al., 2014).

A third group includes studies focusing on eco-certification, usually represented by ISO 14001 or sometimes the European Union Eco-Management and Audit Scheme. These papers are primarily interested in exploring the link with performance, usually mediated by some moderators, such as the ability of environmental certification to improve managerial key factors, resource efficiency or energy consumption (Mensah, 2014).

Performance indicators vary widely but financial indices (ratios operating margins, and profitability) play a central role. In fact, all the three sub-topics often use financial measures to operationalize performance. Focusing attention on corporate social responsibility, some papers integrate financial measure with different values (average market value, excess market value, and Tobin's q). Other studies use corporate social responsibility as a dependent variable, operationalized around some key stakeholders of hotels (employee, community, environment, and clients). Papers within the stream belong to environmental management and eco-certification. They tend to integrate financial measures with competitive indicators (occupancy, average daily rate, RevPAR, sales growth, and market share) and environmental indices (e.g. electricity consumption, eco-labelling and certification, environmental auditing, and environmental education and communication).

\section{Cluster 12 - Market orientation and innovation}

This cluster accounts for 74 papers primarily related to: i) market orientation, ii) environmental management, and iii) innovation, plus some other marginal themes. The underlying discipline is marketing.

Market orientation is presented in many studies as an important antecedent of business performance, operationalized using both operational and financial indicators (Tajeddini and Trueman, 2012). Empirical papers usually combine market orientation with other independent variables or moderators, such as strategy, competitive advantage, hotel quality, competitor orientation, corporate social responsibility, customer satisfaction, customer relationship management, service innovation, total quality, learning orientation, and entrepreneurial orientation (Herath and Mahmood, 2014; Tajeddini, 2015). This list suggests, on one hand, the relevance of market orientation as a determinant of hotel performance, and, on the other, the presence of different approaches that reduce generalizability. In this group, there are some works that combine market orientation with product innovativeness, new service development or simply innovation (Kaliappen and Hilman, 2014).

These papers explain a third sub-group of innovation. This topic is mainly linked to hotel performance, while other studies explore relationships with strategy, or research the antecedents of innovation (Nieves and Segarra-Ciprés, 2015). Innovation is a crucial process, especially during periods of crisis (Campo et al., 2014).

Finally, the second relevant theme is environmental management. Research in this subfield explore links with outcomes and numerous antecedents, including strategic organizational drivers, organization context, strategy, technical efficiency, employees and CEO involvement, 
relationships with destination management, and institutional pressures (Fraj et al., 2015; Shah, 2011).

Market orientation papers operationalize performance mainly using financial performance, sometimes integrated with competitive measures (occupancy, average daily rate, and RevPAR) or clients' perceptions (customer satisfaction, retention, and loyalty). In order to assure comparability between sample composed by different hotel units, some control variables are used, such as category, size, location, age, chain affiliation, and market segments (e.g. leisure and business). Innovation oriented outputs, measure performance mainly in financial terms (operating margins and financial ratios). As noted in previous clusters, environmental papers integrate financial and competitive indices with some environmental measures, usually based on the consumption or saving of scarce resources (e.g. water, electricity, and gas emission).

\section{Cluster 13 - Efficiency}

Cluster 13 is the second largest group with 80 papers and reveals a strong focus on efficiency, measured mainly using DEA models. Four sub-groups were identified: i) efficiency improvement, ii) benchmarking, iii) quality and market orientation, and iv) hotel traits. The underlying feature is efficiency, sometimes integrated with marketing and management.

Efficiency improvement is the crux of the first subgroup of papers. These studies, in order to measure the efficiency variation, tend to favour a longitudinal approach (Yin et al., 2015). Other studies focus on efficiency improvement, proposing innovative methods, such as nonradial DEA or integer DEA (Wu et al., 2010). Finally, some authors depict the role of location and clusters to understand differences in efficiency (Peiró-Signes et al., 2015).

The second subgroup focuses on benchmarking, searching relevant variables to segment a panel of hotels, in order to create innovative competitive sets. Papers suggest a wide stream of variables and topics: technology gaps, technological and efficiency changes, mutual learning strategies between leisure and business hotels, between hotels with higher and lower attractiveness, and between structures more focused on production or on marketing operations (Tsang and Chen, 2013).

Market orientation is the predominant theme of third subgroup. Papers explore the effect of efficiency generated by customer satisfaction, market orientation, marketing expenses, ecommerce, branding, quality certification, and service quality (Kim and Cha, 2002).

Hotel traits represent the most popular independent variable of the second subgroups, which is predominantly influenced by the work of Assaf. This author has explored the role played by size and location for Slovenian casinos (Assaf et al., 2013); size, star, location, age for Australian hotels (Assaf and Agbola, 2014); scale, size, and management experience (Assaf et al., 2011).

The last three sub-groups operationalize performance mainly using financial and competitive indicators. Papers focused on hotel traits measure performance primarily using economic margins, financial ratios and more rarely cash-flows. By contrast, average daily rate, occupancy, RevPAR, market share, sales growth is prevalent for market orientation and benchmarking studies. However, the most "innovative" indicators are those proposed by efficiency papers. In fact, the basic premise of this research stream is to avoid the use of single input/output indicators and to favour the multiple use of inputs and outputs. Inputs usually include number of employees (sometimes articulated between managers, employees and family members), capital investment (book value, invested capital, and number of beds), operational costs, number of guestrooms, while output are mainly represented by sales, occupancy, and value added. 


\section{Cluster 14 - Job satisfaction}

This final cluster is the largest group with 91 papers. The topic of this cluster is job satisfaction, usually operationalized as a dependent variable, while antecedents are related to four sub-groups: i) work engagement, ii) organizational citizenship behaviour (OCB), iii) conflict and facilitation, and iv) leadership, empowerment and knowledge sharing. The discipline of this cluster is HRM.

Work engagement refers to "a positive, fulfilling, work-related state of mind that is characterized by vigour, dedication, and absorption" (Schaufeli et al., 2002, p. 74). Employees who feel energetic, are enthusiastic and are immersed in their work, have desirable job outcomes, such as reduced turnover levels, quality performance in the workplace, and higher levels of job and career satisfaction (Karatepe, 2015). Generally speaking, this first group is strongly related to the work of Karatepe. Work engagement fully mediates the effect of organizational justice (employees' perceptions of fairness in the workplace) on affective organizational commitment, job performance and extra-role customer service (Karatepe, 2011). The use of work engagement as a moderator is proposed in other papers: the effects of co-worker and supervisor support on career satisfaction, service recovery performance, job performance, and creative performance. In other studies, work engagement is used a mediator of "polychronicity" (number of tasks) (Karatepe et al., 2013), organizational politics (organizational members attempt either directly or indirectly to influence other members, in an attempt to achieve personal or group objectives) (Karatepe, 2013), challenge stressors (work overload and job responsibility) (Karatepe et al., 2014), hope on job performance (Karatepe, 2014).

Organizational citizenship behaviour (OCB) is the second sub-theme analysed by this cluster. Customer-contact employee attitude and behaviour influence the consumer satisfaction. Their discretional behaviours not formally prescribed by the organization is called OCB and it influences the quality of service delivered (Wei et al., 2012). Thus, it is of interest to identify the antecedents of OCB to stimulate this behaviour and to increase service quality. OCB is a multidimensional construct and papers explore some determinants, such as emotional intelligence and emotional labour (Ramachandran et al., 2011), employee's workload, HRM practices (training, performance appraisal and information sharing) (Suan and Nasurdin, 2014).

Leadership, empowerment and knowledge sharing are mainly determinants of work engagement. Concerning leadership, papers explore the positive effects of membership, team creative performance, and learning, responsiveness (Wu \& Chen, 2015). Empowerment primarily refers to leadership and it is linked with customers' perception of service quality and knowledge sharing, which is often cited as a source of innovation or service innovative behaviour (Kim and Lee, 2013).

Conflict and facilitation is the last subgroup. Karatepe, as a prominent author, has examined this topic in the double relationship between work-family context. "Although employees are expected to balance the demands of their work (nonworking) and nonworking (work) lives, their participation in both work (nonworking) and nonworking (work) domains result in conflict. Specifically, employees experience work-family conflict and family-work conflict" (Karatepe and Kilic, 2007, p. 238). Papers explore work-family relationships considering the role of supervisor support (Karatepe and Kilic, 2007), job embeddedness (Karatepe and Demir, 2014), the role of exhaustion and emotional displays (Zhao et al., 2014).

This cluster operationalizes performance mainly in term of job satisfaction, sometimes integrated with financial and competitive indices. More rarely, papers consider customer satisfaction. Job performance is usually subjectively measured and it is variously operationalized, when considering perspectives accepted in the literature (as task performance 
and contextual performance, typically analysed in comparison with employees at the same rank). Each component is analysed using a set of questions.

\section{Discussion and conclusions}

This paper explores two research questions, the first related to the general trends within the hotel performance study stream, and the second one focuses on topics. Paragraph 5.1 outlines some conclusions related to trends, while $\S 5.2$ illustrates a few relevant themes. Both sections distinguish between theoretical and practical implications. Finally, $\S 5.3$ reports some study limitations.

\subsection{Trends in hotel performance literature}

Concerning the first research question, the findings reveal an upward trajectory, with $56 \%$ of papers published in the $4^{\text {th }}$ time period (2011-2015) and accounts for 409 papers, while the first period (1996-2000) consists only of 32 papers. This evidence confirms the centrality of performance measurement for researchers and practitioners. Behind this impressive number of papers, there is an increase in the number of journals, moving from 17 ( $1^{\text {st }}$ time period) to 111 ( $4^{\text {th }}$ time period). Journals outside the top ten in terms of volume, non-leading and nontop scoring papers play a pivotal role, both in terms of percentage (roughly 50\%) and citations (roughly 35\%-40\%). Top ten, leading and top scoring articles account for higher citations per papers. The gap moves from 38\% (top scoring, 15.9 compared to 11.5 ), to $46 \%$ (top ten, 16.1 compared to 11.1), to 56\% (leading, 17.2 compared to 11.0). Based on the results from RQ1, some trends are drawn. These conclusions are in line with previous literature reviews and in particular with the work of Sainaghi et al. $(2013,2017)$.

General trend 1. - Performance measurement is a research stream in ascent, both in terms of articles and journals.

General trend 2. - Scholars performing literature reviews on performance measurement should not exclude journals outside the top ten in terms of volume, non-leading, non-top scoring journals, given their quantitative (number of papers) and qualitative (number of citations) relevance.

General trend 3. - Top scoring, top ten and especially leading journals assume, on average, higher citations per paper. The gap with non-top scoring, non-top ten, non-leading moves respectively from $38 \%$, to $46 \%$ and to $56 \%$.

These conclusions are relevant for practitioners too. The first proposition suggests increasing attention of researchers on performance measurement systems and more generally on results' antecedents. Therefore, managers and entrepreneurs can find some relevant observations within this literature stream.

\subsection{Conceptual map of topics}

Concerning the second research question (topics), the methodology used, based on crosscitations and network analysis, has drawn a detailed picture, articulated in 14 clusters with some sub-fields, as reported in Table 6. It is an original map, that helps to understand the complexity of this research area and the broad use of different determinants of hotel performance, mainly studied inside the firm. 
Table 6. Clusters: main topics and sub-fields

\begin{tabular}{|c|c|c|c|c|c|c|c|}
\hline Clusters & Sub-field 1 & Sub-field 2 & Sub-field 3 & Sub-field 4 & Sub-field 5 & Tot & tal \\
\hline 1. HRM (qualitative) & HRM (qualitative) & & & & & & \\
\hline Papers (\#) & 6 & & & & & 6 & $1 \%$ \\
\hline Year (mean) & 2011 & & & & & 2011 & \\
\hline 2. External determinants & Monetary policy & Business cycle & $\begin{array}{l}\text { Crisis \& external } \\
\text { shocks }\end{array}$ & & & & \\
\hline Papers (\#) & 5 & 4 & 3 & & & 12 & $2 \%$ \\
\hline Year (mean) & 2011 & 2012 & 2010 & & & 2011 & \\
\hline $\begin{array}{l}\text { 3. Soft internal } \\
\text { determinants }\end{array}$ & $\begin{array}{c}\text { Performance } \\
\text { measurement systems }\end{array}$ & $\begin{array}{l}\text { Information } \\
\text { technology }\end{array}$ & Relational capabilities & Intellectual capital & $\begin{array}{l}\text { Competitive } \\
\text { strategy }\end{array}$ & & \\
\hline Papers (\#) & _10 & 9. & 9 & - & 5 & 40 & $5 \%$ \\
\hline Year (mean) & 2009 & 2012 & 2008 & $(-2012-)$ & 2008 & 2010 & \\
\hline 4. Diversification & $\begin{array}{c}\text { Performance } \\
\text { measurement systems }\end{array}$ & $\begin{array}{l}\text { Diversification } \\
\text { strategies }\end{array}$ & HRM & $\begin{array}{l}\text { Organisational } \\
\text { competences }\end{array}$ & Technology & & \\
\hline Papers (\#) & 16 & 10 & 6 & -5 &. $.4 \ldots$ & 41 & $6 \%$ \\
\hline Year (mean) & 2008 & 2010 & 2006 & $(-2012-)$ & 2013 & 2009 & \\
\hline 5. HRM (antecedents) & HRM practices & Agglomeration & Others & & & & \\
\hline Papers (\#) & 29 & 11. & 4 & & & 44 & $6 \%$ \\
\hline Year (mean) & 2010 & 2012)$. & 2011 & & & 2010 & \\
\hline 6. Competitive strategy & Competitive strategy & Sales determinants & Outsourcing & Benchmarking & & & \\
\hline Papers (\#) & 15 & 11 & 10 & 9 & & 45 & $6 \%$ \\
\hline Year (mean) & 2010 & 1 & 2007 & 2008 & & 2008 & \\
\hline $\begin{array}{l}\text { 7. Performance } \\
\text { measurement systems }\end{array}$ & $\begin{array}{l}\text { Non-accounting } \\
\text { measures }\end{array}$ & BSC approach & Accounting indices & Others & & & \\
\hline Papers (\#) & 21 & 15 & 13 & 6 & & 55 & $8 \%$ \\
\hline Year (mean) & 2010 & I 2008 & 2006 & 2010 & & 2008 & \\
\hline 8. Social media & $\begin{array}{l}\text { Social media \& online } \\
\text { reviews }\end{array}$ & Website & Market orientation & $\begin{array}{c}\text { Environmental } \\
\text { management }\end{array}$ & Others & & \\
\hline Papers (\#) & 16 & 14 & 12 & $\underline{9}$. & 5 & 56 & $8 \%$ \\
\hline Year (mean) & $2012 \%$ & 2010 & 2005 & (2012.? & 2006 & 2009 & \\
\hline 9. Marketing \& brand & Brand management & Pricing & Marketing strategies & & & & \\
\hline Papers (\#) & 27 & 19 & 13 & & & 59 & $8 \%$ \\
\hline Year (mean) & 2011 & 2011 & 2011 & & & 2011 & \\
\hline $\begin{array}{l}\text { 10. Service quality \& } \\
\text { customer satisfaction }\end{array}$ & Customer satisfaction & Service quality & Others & & & & \\
\hline Papers (\#) & 27 & 24 & 11 & & & 62 & $8 \%$ \\
\hline Year (mean) & 2010 & 2010 & 2009 & & & 2010 & \\
\hline $\begin{array}{l}\text { 11. Environmental } \\
\text { management, corporate } \\
\text { social responsibility }\end{array}$ & $\begin{array}{l}\text { Environmental } \\
\text { management }\end{array}$ & $\begin{array}{l}\text { Corporate social } \\
\text { responsibility }\end{array}$ & Eco-certification & & & & \\
\hline Papers (\#) & $\underline{32}$. & 23. & 13 & & & 68 & $9 \%$ \\
\hline Year (mean) & $2011 ?$ & $(2011)$ & 2009 & & & 2011 & 7 \\
\hline $\begin{array}{l}\text { 12. Market orientation \& } \\
\text { innovation }\end{array}$ & Market orientation & $\begin{array}{l}\text { Environmental } \\
\text { management }\end{array}$ & Innovation & Others & & & \\
\hline Papers (\#) & 33. & 22 & 16 & 3 & & 74 & $10 \%$ \\
\hline Year (mean) & 2011 . & 2010 & 2012 & 2011 & & 2011 & D \\
\hline 13. Efficiency & Efficiency improvement & Benchmarking & $\begin{array}{l}\text { Quality \& market } \\
\text { orientation }\end{array}$ & Hotel traits & Others & & \\
\hline Papers (\#) & 20 & 19 & 18 & 16 & 7 & 80 & $11 \%$ \\
\hline Year (mean) & 2011 & 2009 & 2010 & 2010 & 2012 & 2010 & \\
\hline $\begin{array}{l}\text { 14. HRM (Job } \\
\text { satisfaction) }\end{array}$ & Work engagement & $\begin{array}{c}\text { Organisational } \\
\text { citizenship behaviour }\end{array}$ & Conflict \& facilitation & $\begin{array}{c}\text { Leadership, } \\
\text { empowerment \& } \\
\text { knowledge sharing }\end{array}$ & Others & & \\
\hline Papers (\#) & 26 & 19 & 20 & 16 & 10 & 91 & $12 \%$ \\
\hline Year (mean) & $(-2012=)$ & 2010 & ( & $(-2012=)$ & 2010 & 2011 & D \\
\hline TOTAL & & & & & & 733 & $100 \%$ \\
\hline Year (mean) & & & & & & 2010 & \\
\hline
\end{tabular}

Legend: squared years depict declining trends. $\Gamma_{-}^{-} \mid=$sub-topics related to classical performance measurement systems. to strategic management. Years market by a circle show emerging evolution. $\quad, \quad=$ sub-topics related to HRM $=$ sub-topics related to technology. $(\because j)$ sub-topics related to environmental management. Values not marked are in line with the sample year mean (2010). Trends are not specified for cluster 1 and 2 given the small amount of papers. 
Proposition 1. - Performance measurement is an articulated research stream, which needs to be analysed with a focus on internal determinants.

It is interesting to note, that some themes are evident in more than one cluster: environmental management appears in cluster 7,11 and 12; HRM in clusters 1, 4, 5, 14; competitive strategy 3 and 6; service quality 10 and 13; market orientation 7,12 and 13. These results are a "value added" of the proposed method, that analyses topics and sub-themes considering existing relationships based on cross-citations. In previous reviews these links were missed and each topic was analysed separately. Table 6 suggests, that market innovation (cluster 12) is linked to innovation and environmental management; knowing this link, can help researchers and practitioners to understand, on one side, the complexity of this topic, and, on the other, some emerging relationships, such as the increasing sensibility of many clients on environmental management. Another example confirms the relevance of this point: such as cluster 8 analysis of performance measurement systems, a central topic for this paper. This group includes traditional works based on accounting measures, but also studies rooted in the BSC approach and contributes researching or proposing non-accounting indices.

The conceptual map represented in Table 6 introduces a new topic of segmentation compared to previous reviews in hotel and performance research stream. In fact, as analysed in Section 2.1 , the actual classifications are primarily based on an ex-ante framework (such as the BSC). While in this paper, the 14 clusters are based on an inductive approach, based on crosscitations.

Proposition 2. - Performance measurement topics are articulated in some subfields; those links help to understand the complexity and inter relationships among different sub-themes.

A literature review should suggest a research agenda, identifying emerging topics (or subtopics) and declining research streams. Based on the average year of publication reported in Table 6, some trends are described. In this analysis cluster 1 (6 papers) and 2 (12 papers) are excluded, given their small size. Concerning declining clusters, there are four groups reporting relatively older papers. These clusters are: 4. diversification (2009); 6. competitive strategy (2008); 7. performance measurement systems (2008); 8. social media (2008). They attract 197 papers and represent $27 \%$ of the whole sample. A possible explanation is related to the saturation point reached by these topics, widely explored and researched in hospitality and tourism literature. In terms of disciplines, the first two clusters are mainly related to strategic management; performance measurement systems are based on accounting and, finally, social media on marketing.

Cluster trend 1. - Four clusters depicts declining trends; they are: diversification, competitive strategy, performance measurement systems, and social media.

By contrast four groups account for the highest value (always the year 2011): 9. marketing and brand, 11. environmental management, corporate social responsibility and ecocertification, 12. market orientation and innovation, and 14. HRM (job satisfaction). In terms of disciplines, marketing (clusters 9 and 12), environmental management (cluster 11), stakeholder management (cluster 11), and human resource management (cluster 14) play a pivotal role. Concerning marketing, it has also appeared in the declining cluster 8 . This apparent paradox is easily explained, when considering the different focus of clusters 9 and 12 , on one hand, and cluster 8 , on the other. In the case of declining trends, marketing was operationalized as "social media", while in the emerging ones, it centres on brand (cluster 9) or it is associated with environmental management and innovation (cluster 12). 
Cluster trend 2. - Four clusters depict emerging trends; they are: marketing and brand; environmental management, corporate social responsibility and eco-certification; market orientation and innovation; HRM (job satisfaction).

Now the considering the sub-topics. A first observation concerns the 15 declining sub-topics: two of them are included in "others" papers and therefore not analysed. Seven sub-topics can be grouped around classical performance measurement systems (clusters 3 and 4), based on accounting indices (cluster 7) and BSC (cluster 7) - a framework developed at the beginning of the 90s -, sales determinants (cluster 6) or benchmarking (clusters 6 and 13). Collectively, this suggest a research saturation of this stream, given the high number of contributes mainly developed during the 90s. A second small group includes four sub-topics mainly focused on strategic management; they are: relational capabilities (cluster 3), competitive strategy (cluster 3), outsourcing (cluster 6), market orientation (cluster 8). Strategy and in particular competitive strategy has attracted many papers especially during the $80 \mathrm{~s}$ and $90 \mathrm{~s}$, after the development of Porter's approach, based on activities (the value chain). The remaining two sub-topics are sparse and consider: eco-certification (cluster 11) and HRM analysed in the field of diversification strategy (cluster 4).

This finding is coherent with the work of Pnevmatikoudi and Stavrinoudis (2016) and it underlines the necessity to give more attention to non-financial indicators.

Cluster trend 3. - Declining sub-topics are centred around accounting or financial performance measurement systems and competitive strategy.

In contrast, 18 sub-topics show an emerging trend with three of them belong to the residual group "others" and therefore are not analysed. The first basket includes five themes mainly interrelated to human resource management; they are: intellectual capital (cluster 3), organizational competences (cluster 4), work engagement (cluster 14); conflict and facilitation (cluster 14); leadership, empowerment and knowledge sharing (cluster 14). The increasing relevance of human resource management is largely related to the nature of the hotel, that it is a high-contact system organization, where employees play a pivotal role in many processes. In this sense, it is unsurprising that employee motivation, participation, satisfaction are important determinants or moderators among many marketing, strategic, efficiency, and competitive antecedents of performance.

A second group includes four sub-topics related to technology; they are: information technology (cluster 3), technology (cluster 4), social media and online reviews (cluster 8), innovation (cluster 12). Technology is able to change internal processes dramatically (increasing efficiency) and external relationships (with main stakeholders, clients and suppliers). Coherent with this approach, technology is related to different clusters: from internal soft determinants (cluster 3) to diversification (cluster 4), form social media (cluster 8 ) to market orientation and innovation (cluster 12).

A third group includes five codes mainly related to environmental management (cluster 8 and 11), corporate social responsibility (cluster 11), market orientation (cluster 12, analysed in conjunction with environmental management, as reported in Table 6), and agglomeration (cluster 5). The unifying element here is the link with the external hotel environment. They need to achieve environmental standards and to re-design market orientation, to consider a wide spectrum of stakeholders (corporate social responsibility) and to evaluate relationships with neighbouring organizations (agglomeration). Finally, there is a sparse sub-group represented by efficiency (cluster 13). 
Cluster trend 4. - These sub-topics are focused on HRM, technology and environmental variables.

The analysis of declining and rising clusters and sub-topics help researchers to identify some possible future research directions. A first possible agenda is to combine emerging topics with declining ones. In this sense, HRM, technology and environmental management can renew some traditional issues, such as performance measurement systems, competitive strategy and traditional marketing. Table 6 contains confirmation about this point, in fact market orientation analysed in the field of social media (cluster 8) is a declining sub-topic, but in conjunction with environmental management and innovation is an emerging theme (cluster 12). A second research implication is related to the paucity of papers focused on technology and innovation. Table 6 accounts for only 4 sub-topics (as previously analysed) that represent $6 \%$ of the sample. Online reviews (one of the four themes) have been a game changer for practitioners, while Table 6 suggests a limited impact for researchers. The access to big data related to customer perception can profoundly reconfigure the hotel performance research stream. Finally, focusing the attention at a holistic level (Table 6) the previous research is mainly divided by discipline (as previously depicted analysing the 14 clusters). A possible future research agenda could increase relationships between these disciplines.

The analysis conducted for this literature review, has mainly focused on theoretical implications. Now it is important to trace some stimuli also for practitioners. Some suggestions are routed in the clusters' trends. Three of them indicate the importance for hotel organizations to enlarge the dialogue with external stakeholders (clusters 9, 11 and 12). The ability to meet the expectations of external actors represent an important determinant or a moderator of firm's performance. Given the increasing sensibility of resource utilization, environmental management (and therefore an environmental performance measurement) assumes (and will assume) an increasing importance.

If this first movement focuses on external stakeholders, on the other side, cluster 14 indicates the relevance of internal processes. In fact, HRM is a key point. The ability to create a positive relationship with employees, mainly managing work engagement, conflict and facilitation, leadership, empowerment and knowledge sharing is able to moderate and in some cases to influence hotel performance.

Finally, the analysis of emerging sub-topics, as previously analytically examined, suggest the increasing importance of technology and, HRM and environmental practices.

\subsection{Limitations and further research}

This work presents some limitations that are identified primarily to suggest future research agendas. First, the study uses the SCOPUS database which despite being authoritative will result in some research outputs not being accessible because of their unavailability at the time of the research. The SCOPUS database is not exhaustive of all the possible publications relating to hotel performance measurement, and we do not include books in our sample. Second, topics and sub-topics were identified from reading the papers. This approach, on one side, favours a very detailed analysis, as reported in Table 6 , but, on the other, it increases subjectivity and reduces reliability. Some recent reviews (i.e. Sainaghi et al., 2017) propose an objective method, based on key-works and computer-aided text analysis (CATA). Further research can use this technique to compare results achieved using the two approaches. Third, this paper focuses on trends and topics and for this reason, does not explore methods and performance indicators, as developed in some previous reviews. Future research can analyse these relevant aspects with the aim to verify the prevailing methods and performance indicators used. Fourth, given the exploratory role of this paper, clusters are identified and analysed but this study (primarily for space constrains) does not develop a comprehensive 
model, for creating a system able to explore relationships among different clusters and subgroups, as proposed, for example, by Sainaghi (2010a), using the BSC.

\section{REFERENCES}

Ahmad, R. and Scott, N. (2014) "Managing the front office department: Staffing issues in Malaysian hotels", Anatolia, Vol. 25, No. 1, pp. 24-38.

Albayrak, T. (2015) "Importance Performance Competitor Analysis (IPCA): A study of hospitality companies", International Journal of Hospitality Management, Vol. 48, pp. 135-142.

Albayrak, T. and Caber, M. (2015) "Prioritisation of the hotel attributes according to their influence on satisfaction: A comparison of two techniques", Tourism Management, Vol. 46, pp. 43-50.

Alonso-Almeida, M. M. and Bremser, K. (2013) "Strategic responses of the Spanish hospitality sector to the financial crisis", International Journal of Hospitality Management, Vol. 32, pp. 141148.

Alrousan, R. M., Bader, M. A. and Abuamoud, I. (2015) "Stakeholders approach in influencing corporate social responsibility: a case study at two hotels in Jordan", International Journal of Tourism Policy, Vol. 6 No. 1, pp. 17-28.

Assaf, A. and Agbola, F. (2014) "Efficiency Analysis of the Australian Accommodation Industry: A Bayesian Output Distance Function", Journal of Hospitality and Tourism Research, Vol. 38, No. 1, pp. 116-132.

Assaf, A. G. and Josiassen, A. (2012) "Identifying and ranking the determinants of tourism performance: A global investigation", Journal of Travel Research, Vol. 51 No. 4, pp. 388-399.

Assaf, A. G., Cvelbar, L. K. and Pahor, M. (2013) "Performance drivers in the casino industry: Evidence from Slovenia", International Journal of Hospitality Management, Vol. 32, pp. 149154.

Assaf, A. G., Deery, M. and Jago, L. (2011) "Evaluating the performance and scale characteristics of the Australian restaurant industry", Journal of Hospitality \& Tourism Research, Vol. 35, No. 4, pp. 419-436.

Assaf, A. G., Josiassen, A., Cvelbar, L. K. and Woo, L. (2015) "The effects of customer voice on hotel performance", International Journal of Hospitality Management, Vol. 44, pp. 77-83.

Atkinson, H. and Brander Brown, J. (2001) "Rethinking performance measures: assessing progress in UK hotels", International Journal of Contemporary Hospitality Management, Vol. 13, No. 3, pp. 128-136.

Avcikurt, C., Altay, H. and Oguzhan Ilban, M. (2011) "Critical success factors for small hotel businesses in Turkey: an exploratory study", Cornell Hospitality Quarterly, Vol. 52, No. 2 , pp. 153-164.

Baggio, R. and Klobas, J. (2017) Quantitative Methods in Tourism: A Handbook, (II ed.), Bristol, UK: Channel View.

Baggio, R. and Sainaghi, R. (2011) "Complex and chaotic tourism systems: towards a quantitative approach", International Journal of Contemporary Hospitality Management, Vol. 23 No. 6, pp. 840-861.

Baggio, R. and Sainaghi, R. (2016) "Mapping time series into networks as a tool to assess the complex dynamics of tourism systems", Tourism Management, Vol. 54, pp. 23-33.

Baggio, R., Scott, N. and Cooper, C. (2010) "Network science - a review focused on tourism", Annals of Tourism Research, Vol. 37 No. 3, pp. 802-827.

Baumgartner, H. and Pieters, R. (2003) "The structural influence of marketing journals: A citation analysis of the discipline and its subareas over time", Journal of marketing, Vol. 67 No. 2, pp. 123-139.

Benckendorff, P. (2009), "Themes and trends in Australian and New Zealand tourism research: A social network analysis of citations in two leading journals (1994-2007)", Journal of Hospitality and Tourism Management, Vol. 16 No. 1, pp. 1-15.

Benckendorff, P. and Zehrer, A. (2013) "A network analysis of tourism research", Annals of Tourism Research, Vol. 43, pp. 121-149.

Bergin-Seers, S. and Jago, L. (2007) "Performance Measurement in Small Motels in Australia", Tourism and hospitality Research, Vol. 7, No. 2, pp. 144-155. 
Bernini, C. and Guizzardi, A. (2015) "Improving performance measurement and benchmarking in the accommodation sector", International Journal of Contemporary Hospitality Management, Vol. 27 No. 5, pp. 980-1002.

Blondel, V. D., Guillaume, J. L., Lambiotte, R. and Lefebvre, E. (2008) "Fast unfolding of communities in large networks", Journal of Statistical Mechanics, P10008.

Bontis, N., Janošević, S. and Dženopoljac, V. (2015) "Intellectual capital in Serbia's hotel industry", International Journal of Contemporary Hospitality Management, Vol. 27, No. 6, pp. 13651384.

Brander Brown, J. and McDonnell, B. (1995) "The balanced score-card: short-term guest or long-term resident?", International Journal of Contemporary Hospitality Management, Vol. 7, No. 2/3, pp. 7-11.

Campo, S., Díaz, A. and Yagüe, M. (2014) "Hotel innovation and performance in times of crisis", International Journal of Contemporary Hospitality Management, Vol. 26, No. 8, pp. 12921311.

Campopiano, G., Minola, T. and Sainaghi, R. (2016) "Students Climbing the Entrepreneurial Ladder: Family Social Capital and Environment-related Motives in Hospitality and Tourism", International Journal of Contemporary Hospitality Management, Vol. 28 No. 6, pp. 1115-1136.

Cardillo, A., Scellato, S. and Latora, V. (2006) "A topological analysis of scientific coauthorship networks", Physica A, Vol. 372, pp. 333-339.

Casanueva, C., Gallego, A. and Revilla, M. A. (2015) "Access and mobilization of network resources and competitive advantage in hotels: A conceptual framework", International Journal of Contemporary Hospitality Management, Vol. 27, No. 6, pp. 1279-1300.

Chan, E. S. and Hsu, C. H. (2016) "Environmental management research in hospitality", International Journal of Contemporary Hospitality Management, Vol. 28 No. 5, pp. 886-923.

Chand, M. (2010) "The impact of HRM practices on service quality, customer satisfaction and performance in the Indian hotel industry", International Journal of Human Resource Management, Vol. 21 No. 4, pp. 551-566.

Chand, M. and Katou, A. A. (2007) "The impact of HRM practices on organisational performance in the Indian hotel industry", Employee Relations, Vol. 29 No. 6, pp. 576-594.

Charoensuk, S., Wongsurawat, W. and Khang, D. B. (2014) "Business-IT Alignment: A practical research approach", The Journal of High Technology Management Research, Vol. 25, No. 2, pp. 132-147.

Chen, C. M. and Chang, K. L. (2012) "Diversification strategy and financial performance in the Taiwanese hotel industry", International Journal of Hospitality Management, Vol. 31, No. 3, pp. 1030-1032.

Chen, C. M., Lin, Y. C. and Tsai, Y. C. (2015) "How does advertising affect the price elasticity of lodging demand? Evidence from Taiwan", Tourism Economics, Vol. 21, No. 5, pp. 10351045.

Chen, J. S. and Wang, W. (2015) "Foreign labours in Arctic destinations: seasonal workers' motivations and job skills", Current Issues in Tourism, Vol. 18, No. 4, pp. 350-360.

Chen, J., Koh, Y. and Lee, S. (2011) "Does the market care about RevPAR? A case study of five large US lodging chains", Journal of Hospitality \& Tourism Research, Vol. 35, No. 2, pp. 258-273.

Chen, M. H. (2015) "Understanding the impact of changes in consumer confidence on hotel stock performance in Taiwan", International Journal of Hospitality Management, Vol. 50, pp. 5565.

Chen, M. H., Kim, W. G. and Liao, C. N. (2009) "The impact of government weekend policy changes and foreign institutional holdings on weekly effect of tourism stock performance", Journal of Hospitality \& Tourism Research, Vol. 33, No. 2, pp. 139-160.

Chung, T. and Law, R. (2003) "Developing a performance indicator for hotel websites", International Journal of Hospitality Management, Vol. 22 No. 1, pp. 119-125.

Chung, W. and Kalnins, A. (2001) "Agglomeration Effects and Performance: A Test of the Texas Lodging Industry", Strategic Management Journal, Vol. 22(10), pp. 969-988.

d'Angella, F., De Carlo, M. and Sainaghi, R. (2010) "Archetypes of destination governance: a comparison of international destinations", Tourism Review, Vol. 65 No. 4, pp. 61-73. 
da Fontoura Costa, L., Rodrigues, A., Travieso, G. and Villas Boas, P. R. (2007) "Characterization of complex networks: A survey of measurements", Advances in Physics, Vol. 56 No. 1, pp. 167242.

Davidson, M. C., McPhail, R. and Barry, S. (2011) "Hospitality HRM: past, present and the future", International Journal of Contemporary Hospitality Management, Vol. 23 No. 4, pp. 498-516.

De Vita, G. and Tekaya, A. (2015) "Hotel outsourcing under asset specificity:«The good, the bad and the ugly»", Tourism Management, Vol. 47, pp. 97-106.

Denton, G. A. and White, B. (2000) "Implementing a balanced-scorecard approach to managing hotel operations: the case of white lodging services", The Cornell Hotel and Restaurant Administration Quarterly, Vol. 41, No. 1, pp. 94-107.

Dewally, M., Shao, Y. and Singer, D. (2013) "The liquidity crisis: evidence from the US hospitality industry", Tourism Economics, Vol. 19, No. 3, pp. 545-563.

Fortunato, S. (2010) "Community detection in graphs", Physics Reports, Vol. 486 No. 3-5, pp. 75-174.

Fraj, E., Matute, J. and Melero, I. (2015) "Environmental strategies and organizational competitiveness in the hotel industry: The role of learning and innovation as determinants of environmental success", Tourism Management, Vol. 46, pp. 30-42.

García-Lillo, F., Úbeda-García, M. and Marco-Lajara, B. (2016) "The intellectual structure of research in hospitality management: A literature review using bibliometric methods of the journal International Journal of Hospitality Management", International Journal of Hospitality Management, Vol. 52, pp. 121-130.

Giannotti, C., Mattarocci, G. and Spinelli, L. (2011) "The role of portfolio diversification in the hotel industry: Evidence from the Italian market”, EuroMed Journal of Business, Vol. 6, No. 1, pp. 24-45.

Gomezelj, D. O. (2016) "A systematic review of research on innovation in hospitality and tourism", International Journal of Contemporary Hospitality Management, Vol. 28 No. 3, pp. 516-558.

Gross, M. J., Gao, H. and Huang, S. S. (2013) "China hotel research: A systematic review of the English language academic literature", Tourism Management Perspectives, Vol. 6, pp. 68-78.

Gursoy, D. and Sandstrom, J. K. (2016) "An updated ranking of hospitality and tourism journals", Journal of Hospitality \& Tourism Research, Vol. 40 No. 1, pp. 3-18.

Hall, C. M. (2011) "Publish and perish? Bibliometric analysis, journal ranking and the assessment of research quality in tourism", Tourism Management, Vol. 32 No. 1, pp. 16-27.

Harrington, R. and Ottenbacher, M. (2011) "Strategic management: An analysis of its representation and focus in recent hospitality research", International Journal of Contemporary Hospitality Management, Vol. 23 No. 4, pp. 439-462.

Harris, P. J. and Mongiello, M. (2001) "Key performance indicators in European hotel properties: general managers' choices and company profiles", International Journal of Contemporary Hospitality Management, Vol. 13, No. 3, pp. 120-128.

Herath, H. M. and Mahmood, R. (2014) "Strategic orientations and SME performance: Moderating effect of absorptive capacity of the firm", Asian Social Science, Vol. 10, No. 13, pp. 95-106.

Howey, R. M., Savage, K. S., Verbeeten, M. J. and Van Hoof, H. B. (1999) "Tourism and hospitality research journals: Cross-citations among research communities", Tourism Management, Vol. 20 No. 1, pp. 133-139.

Hua, N. (2016) "E-commerce performance in hospitality and tourism", International Journal of Contemporary Hospitality Management, Vol. 28 No. 9, pp. 2052-2079.

Huang, K. T., Wang, J. C. and Wang, Y. C. (2015) "Analysis and benchmarking of greenhouse gas emissions of luxury hotels", International Journal of Hospitality Management, Vol. 51, pp. 56-66.

Jang, S. and Park, K. (2011) "Hospitality finance research during recent two decades: subjects, methodologies, and citations", International Journal of Contemporary Hospitality Management, Vol. 23 No. 4, pp. 479-497.

Janković, S. and Krivačić, D. (2014) "Environmental accounting as perspective for hotel sustainability: Literature review", Tourism and hospitality management, Vol. 20 No. 1, pp. 103120. 
Jarboui, S., Guetat, H. and Boujelbène, Y. (2015) "Evaluation of hotels performance and corporate governance mechanisms: Empirical evidence from the Tunisian context", Journal of Hospitality and Tourism Management, Vol. 25, pp. 30-37.

Kaliappen, N. and Hilman, H. (2014) "Does Service Innovation Act as a Mediator in Differentiation Strategy and Organizational Performance Nexus? An Empirical Study", Asian Social Science, Vol. 10, No. 11, pp. 123-131.

Karatepe, O. M. (2011) "Procedural justice, work engagement, and job outcomes: Evidence from Nigeria", Journal of Hospitality Marketing \& Management, 20 No. 8, pp. 855-878.

Karatepe, O. M. (2013) "Perceptions of organizational politics and hotel employee outcomes: The mediating role of work engagement", International Journal of Contemporary Hospitality Management, Vol. 25, No. 1, pp. 82-104.

Karatepe, O. M. (2014) "Hope, work engagement, and organizationally valued performance outcomes: an empirical study in the hotel industry", Journal of Hospitality Marketing \& Management, Vol. 23, No. 6, pp. 678-698.

Karatepe, O. M. (2015) "The effects of family support and work engagement on organizationally valued job outcomes", Turizam: znanstveno-stručni časopis, Vol. 63 No. 4, pp. 447-464.

Karatepe, O. M. and Demir, E. (2014) "Linking core self-evaluations and work engagement to workfamily facilitation: a study in the hotel industry", International Journal of Contemporary Hospitality Management, Vol. 26No. 2, pp. 307-323.

Karatepe, O. M. and Kilic, H. (2007) "Relationships of supervisor support and conflicts in the workfamily interface with the selected job outcomes of frontline employees", Tourism Management, Vol. 28 No. 1, pp. 238-252.

Karatepe, O. M., Beirami, E., Bouzari, M. and Safavi, H. P. (2014) "Does work engagement mediate the effects of challenge stressors on job outcomes? Evidence from the hotel industry", International Journal of Hospitality Management, Vol. 36, pp. 14-22.

Karatepe, O., Karadas, G., Azar, A. and Naderiadib, N. (2013) "Does Work Engagement Mediate the Effect of Polychronicity on Performance Outcomes? A Study in the Hospitality Industry in Northern Cyprus", Journal of Human Resources in Hospitality and Tourism, Vol. 12, No. 1, pp. 52-70.

Kaushik, A. K., Agrawal, A. K. and Rahman, Z. (2015) "Tourist behaviour towards self-service hotel technology adoption: Trust and subjective norm as key antecedents", Tourism Management Perspectives, Vol. 16, pp. 278-289.

Kayaman, R. and Arasli, H. (2007) "Customer based brand equity: evidence from the hotel industry", Managing Service Quality: An International Journal, Vol. 17 No. 1, pp. 92-109.

Kim, T. T. and Lee, G. (2013) "Hospitality employee knowledge-sharing behaviors in the relationship between goal orientations and service innovative behavior", International Journal of Hospitality Management, Vol. 34, pp. 324-337.

Kim, W. G. and Cha, Y. (2002) "Antecedents and consequences of relationship quality in hotel industry", International Journal of Hospitality Management, Vol. 21, No. 4, pp. 321-338.

Kim, Y., Savage, K. S., Howey, R. M. and Van Hoof, H. B. (2009) "Academic foundations for hospitality and tourism research: A reexamination of citations", Tourism Management, Vol. 30 No. 5, pp. 752-758.

Köseoglu, M. A., Rahimi, R., Okumus, F. Liu, J. (2016) "Bibliometric studies in tourism", Annals of Tourism Research, Vol. 61, pp. 180-198.

Köseoglu, M. A., Sehitoglu, Y. and Craft, J. (2015) “Academic foundations of hospitality management research with an emerging country focus: A citation and co-citation analysis", International Journal of Hospitality Management, Vol. 45, pp. 130-144.

$\mathrm{Ku}$, E. C. (2014) "Putting forth marketing competencies strength with collaborating partners in the hotel industry", Service Business, Vol. 8, No. 4, pp. 679-697.

Lee, C. G. (2011) "The determinants of hotel room rates: Another visit with Singapore's data", International Journal of Hospitality Management, Vol. 30, No. 3, pp. 756-758.

Lee, C. S., Chao, C. W. and Chen, H. I. (2015) "The relationship between HRM practices and the service performance of student interns: Industry perspective", South African Journal of Business Management, Vol. 46, No. 3, pp. 1-10. 
Lee, S. K. and Jang, S. (2015) "Conditional agglomeration externalities in lodging markets", Journal of Hospitality \& Tourism Research, Vol. 39 No. 4, pp. 540-559.

Leonidou, L. C., Leonidou, C. N., Fotiadis, T. A. and Zeriti, A. (2013) "Resources and capabilities as drivers of hotel environmental marketing strategy: Implications for competitive advantage and performance", Tourism Management, Vol. 35, pp. 94-110.

Leung, X. Y., Sun, J. and Bai, B. (2017) "Bibliometrics of social media research: A co-citation and coword analysis", International Journal of Hospitality Management, Vol. 66, pp. 35-45.

Lucas, R. and Deery, M. (2004) "Significant developments and emerging issues in human resource management", International Journal of Hospitality Management, Vol. 23 No. 5, pp. 459-472.

Maier, T. (2012) "International hotel revenue management: Web-performance effectiveness modelling - research comparative", Journal of Hospitality and Tourism Technology, Vol. 3 No. 2, pp. 121137.

McManus, L. (2013) "Customer accounting and marketing performance measures in the hotel industry: Evidence from Australia", International Journal of Hospitality Management, Vol. 33 No. 1, pp. 140-152.

Mensah, I. (2014) "Different shades of green: Environmental management in hotels in Accra", International Journal of Tourism Research, Vol. 16, No. 5, pp. 450-461.

Mia, L. and Patiar, A. (2001) "The use of management accounting systems in hotels: an exploratory study", International Journal of Hospitality Management, Vol. 20, No. 2, pp. 111-128.

Mia, L. and Patiar, A. (2002) "The interactive effect of superior-subordinate relationship and budget participation on managerial performance in the hotel industry: an exploratory study", Journal of Hospitality \& Tourism Research, Vol. 26, No. 3, pp. 235-257.

Mohsin, A. and Lengler, J. (2015) "Service experience through the eyes of budget hotel guests: do factors of importance influence performance dimensions?", Journal of Hospitality and Tourism Management, Vol. 23, pp. 23-34.

Newman, M. E. (2004) "Detecting community structure in networks", The European Physical Journal B-Condensed Matter and Complex Systems, Vol. 38 No. 2, pp. 321-330.

Nieves, J. and Segarra-Ciprés, M. (2015) "Management innovation in the hotel industry", Tourism Management, Vol. 46, pp. 51-58.

O'Neill, J. W. and Carlbäck, M. (2011) "Do brands matter? A comparison of branded and independent hotels' performance during a full economic cycle", International Journal of Hospitality Management, Vol. 30, No. 3, pp. 515-521.

Olsen, M. D. (2004) "Literature in strategic management in the hospitality industry", International Journal of Hospitality Management, Vol. 23 No. 5, pp. 411-424.

Oviedo-García, M. Á. (2016) "Tourism research quality: Reviewing and assessing interdisciplinarity”, Tourism Management, Vol. 52, pp. 586-592.

Paek, S., Xiao, Q., Lee, S. and Song, H. (2013) "Does managerial ownership affect different corporate social responsibility dimensions? An empirical examination of US publicly traded hospitality firms", International journal of hospitality management, Vol. 34, pp. 423-433.

Panagopoulos, A., Kanellopoulos, D., Karachanidis, I. and Konstantinidis, S. (2011) "A comprehensive evaluation framework for hotel websites: The case of chain hotel websites operating in Greece", Journal of Hospitality Marketing \& Management, Vol. 20 No. 7, pp. 695717.

Park, K. and Jang, S. (2014) "Hospitality finance and managerial accounting research: Suggesting an interdisciplinary research agenda", International Journal of Contemporary Hospitality Management, Vol. 26 No. 5, pp. 751-777.

Patiar, A. and Mia, L. (2008) "The interactive effect of market competition and use of MAS information on performance: Evidence from the upscale hotels", Journal of Hospitality \& Tourism Research, Vol. 32, No. 2, pp. 209-234.

Peiró-Signes, A., Segarra-Oña, M. D., Miret-Pastor, L. and Verma, R. (2015) "The effect of tourism clusters on US hotel performance", Cornell Hospitality Quarterly, Vol. 56 No. 2, pp. 155-167.

Pereira-Moliner, J., Font, X., Tarí, J. J., Molina-Azorin, J. F., Lopez-Gamero, M. D. and PertusaOrtega, E. M. (2015) "The Holy Grail: Environmental management, competitive advantage and business performance in the Spanish hotel industry", International Journal of Contemporary Hospitality Management, Vol. 27 No. 5, pp. 714-738. 
Phillips, P. A. (1999) "Performance measurement systems and hotels: a new conceptual framework", International Journal of Hospitality Management, Vol. 18 No. 2, pp. 171-182.

Phillips, P. A. and Moutinho, L. (2014) "Critical review of strategic planning research in hospitality and tourism", Annals of Tourism Research, Vol. 48, pp. 96-120.

Pine, R. and Phillips, P. A. (2005) "Performance comparisons of hotels in China", International Journal of Hospitality Management, Vol. 24 No. 1, pp. 57-73.

Pnevmatikoudi, K. and Stavrinoudis, T. (2016) "Classification of hotel performance measurement indicators presented in international scientific research", European Journal of Tourism Research, Vol. 12, pp. 82-98.

$\mathrm{Qu}, \mathrm{R}$. (2009) "The impact of market orientation and corporate social responsibility on firm performance: evidence from China", Asia Pacific Journal of Marketing and Logistics, Vol. 21, No. 4, pp. 570-582.

Ramachandran, Y., Jordan, P. J., Troth, A. C. and Lawrence, S. A. (2011) "Emotional intelligence, emotional labour and organisational citizenship behaviour in service environments", International Journal of Work Organisation and Emotion, Vol. 4, No. 2, pp. 136-157.

Sainaghi, R. (2006) "From Contents to Processes: Versus a Dynamic Destination Management Model (DDMM)", Tourism Management, Vol. 27 No. 5, pp. 1053-1063.

Sainaghi, R. (2010a) "Hotel performance: state of the art", International Journal of Contemporary Hospitality Management, Vol. 22 No. 7, pp. 920-952.

Sainaghi, R. (2010b) "A meta-analysis of hotel performance, Continental or worldwide style?", Tourism Review, Vol. 65 No. 3, pp. 46-69.

Sainaghi, R. (2010c) "The effects of seasonality on hotels performance: the case of Milan", Anatolia, Vol. 21 No. 1, pp. 173-178.

Sainaghi, R. (2011) "RevPAR determinants of individual hotels: evidences from Milan", International Journal of Contemporary Hospitality Management, Vol. 23 No. 3, pp. 297-311.

Sainaghi, R. (2012) "Tourist expenditures: the state of the art", Anatolia, Vol. 23 No. 2, pp. 217-233.

Sainaghi, R. and Baggio, R. (2014) "Structural social capital and hotel performance: Is there a link?", International Journal of Hospitality Management, Vol. 37 No. 2, pp. 99-110.

Sainaghi, R. and Baggio, R. (2017) "Complexity traits and dynamics of tourism destinations", Tourism Management, Vol. 63, pp. 368-382.

Sainaghi, R. and Canali, S. (2011) "Exploring the effects of destination's positioning on hotels' performance: the Milan case", Tourismos: An International Multidisciplinary Journal of Tourism, Vol. 6 No. 2, pp. 121-138.

Sainaghi, R. and De Carlo, M. (2016) "How to Create Destination Capabilities in the Field of New Product Development", in Pechlaner H. and Innerhofer, E. (Ed), Competence-Based Innovation in Hospitality and Tourism, Routledge, pp. 185-196.

Sainaghi, R., Phillips, P. and Corti, V. (2013) "Measuring hotel performance: Using a balanced scorecard perspectives' approach", International Journal of Hospitality Management, Vol. 34 No. 1, pp. 150-159.

Sainaghi, R., Phillips, P. and Zavarrone, E. (2017) "Performance measurement in tourism firms: A content analytical meta-approach", Tourism Management, Vol. 59, pp. 36-56.

Schaufeli, W. B., Salanova, M., González-Romá, V. and Bakker, A. B. (2002) "The measurement of engagement and burnout: A two sample confirmatory factor analytic approach", Journal of Happiness studies, Vol. 3 No. 1, pp. 71-92.

Serrat, J. M. (2011) "Quality of hotel service and consumer protection: A European contract law approach", Tourism Management, Vol. 32, No. 2, pp. 277-287.

Shah, K. U. (2011) "Strategic organizational drivers of corporate environmental responsibility in the Caribbean hotel industry", Policy Sciences, Vol. 44, No. 4, pp. 321-344.

Sharma, A. and Christie, I. T. (2010) "Performance assessment using value-chain analysis in Mozambique", International Journal of Contemporary Hospitality Management, Vol. 22, No. 3, pp. 282-299.

Sizoo, S., Plank, R., Iskat, W. and Serrie, H. (2005) "The effect of intercultural sensitivity on employee performance in cross-cultural service encounters", Journal of Services Marketing, Vol. 19, No. 4, pp. 245-255. 
Sledge, S., Miles, A. K. and Coppage, S. (2008) "What role does culture play? A look at motivation and job satisfaction among hotel workers in Brazil", The International Journal of Human Resource Management, Vol. 19 No. 9, pp. 1667-1682.

Solnet, D. J., Paulsen, N. and Cooper, C. (2010) "Decline and turnaround: a literature review and proposed research agenda for the hotel sector", Current Issues in Tourism, Vol. 13 No. 2, pp. 139-159.

Sourouklis, C. and Tsagdis, D. (2013) "Workforce diversity and hotel performance: A systematic review and synthesis of the international empirical evidence", International Journal of Hospitality Management, Vol. 34, pp. 394-403.

Suan, C. L. and Nasurdin, A. M. (2014) "An empirical investigation into the influence of human resource management practices on work engagement: the case of customer-contact employees in Malaysia", International Journal of Culture, Tourism and Hospitality Research, Vol. 8 No. 3, pp. 345-360.

Sund, K. J. (2013) "Scanning, perceived uncertainty, and the interpretation of trends: A study of hotel directors' interpretation of demographic change", International Journal of Hospitality Management, Vol. 33, pp. 294-303.

Tajeddini, K. (2015) "Exploring the antecedents of effectiveness and efficiency", International Journal of Hospitality Management, Vol. 49, pp. 125-135.

Tajeddini, K. and Trueman, M. (2012) "Managing Swiss Hospitality: How cultural antecedents of innovation and customer-oriented value systems can influence performance in the hotel industry", International Journal of Hospitality Management, Vol. 31 No. 4, pp. 1119-1129.

Tang, Y. H., Amran, A. and Goh, Y. N. (2014) "Environmental management practices of hotels in Malaysia: stakeholder perspective", International Journal of Tourism Research, Vol. 16, No. 6, pp. 586-595.

Timur, S. and Getz, D. (2008) "A network perspective on managing stakeholders for sustainable urban tourism", International Journal of Contemporary Hospitality Management, Vol. 20 No. 4, pp. 445-461.

Torres, E. N., Singh, D. and Robertson-Ring, A. (2015) "Consumer reviews and the creation of booking transaction value: Lessons from the hotel industry", International Journal of Hospitality Management, Vol. 50, pp. 77-83.

Tsai, H., Pan, S. and Lee, J. (2011) "Recent research in hospitality financial management", International Journal of Contemporary Hospitality Management, Vol. 23 No. 7, pp. 941-971.

Tsang, N. and Hsu, C. (2011) "Thirty years of research on tourism and hospitality management in China: a review and analysis of journal publications", International Journal of Hospitality Management, Vol. 30 No. 4, pp. 886-896.

Tsang, S. S. and Chen, Y. F. (2013) "Facilitating benchmarking with strategic grouping and data envelopment analysis: the case of international tourist hotels in Taiwan", Asia Pacific Journal of Tourism Research, Vol. 18, No. 5, pp. 518-533.

Tsionas, E. G. and Assaf, A. G. (2014) "Short-run and long-run performance of international tourism: Evidence from Bayesian dynamic models", Tourism Management, Vol. 42, pp. 22-36.

Tugores, M. and García, D. (2015) "The impact of innovation on firms' performance: an analysis of the hotel sector in Majorca", Tourism Economics, Vol. 21, No. 1, pp. 121-140.

Ubeda-García, M., Marco-Lajara, B., Sabater-Sempere, V. and García-Lillo, F. (2013) "Does training influence organisational performance? Analysis of the Spanish hotel sector", European Journal of Training and Development, Vol. 37, No. 4, pp. 380-413.

van der Zee, E. and Vanneste, D. (2015) "Tourism networks unravelled; a review of the literature on networks in tourism management studies", Tourism Management Perspectives, Vol. 15, pp. 4656.

Wang, F., Qiu, J. and Yu, H. (2012) "Research on the cross-citation relationship of core authors in scientometrics", Scientometrics, Vol. 91 No. 3, pp. 1011-1033.

Wang, Y. C. and Chung, Y. (2015) "Hotel brand portfolio strategy", International Journal of Contemporary Hospitality Management, Vol. 27 No. 4, pp. 561-584.

Wardle, C. and Buckley, R. (2014) "Tourism citations in other disciplines", Annals of Tourism Research, Vol. 46, pp. 166-168. 
Wei, X., Qu, H. and Ma, E. (2012) "Decisive mechanism of organizational citizenship behavior in the hotel industry-an application of economic game theory", International Journal of Hospitality Management, Vol. 31, No. 4, pp. 1244-1253.

Winata, L. and Mia, L. (2005) "Information technology and the performance effect of managers' participation in budgeting: evidence from the hotel industry", International Journal of Hospitality Management, Vol. 24, No. 1, pp. 21-39.

$\mathrm{Wu}, \mathrm{C}$. M. and Chen, T. J. (2015) "Psychological contract fulfillment in the hotel workplace: Empowering leadership, knowledge exchange, and service performance", International Journal of Hospitality Management, Vol. 48, pp. 27-38.

Wu, J., Liang, L. and Song, H. (2010) "Measuring hotel performance using the integer DEA model", Tourism Economics, Vol. 16, No. 4, pp. 867-882.

Xiao, H. and Smith, S. L. (2008) "Knowledge impact an appraisal of tourism scholarship", Annals of Tourism Research, Vol. 35 No. 1, pp. 62-83.

Yang, J. T., Wan, C. S. and Wu, C. W. (2015) "Effect of internal branding on employee brand commitment and behavior in hospitality", Tourism and Hospitality Research, Vol. 15, No. 4, pp. 267-280.

Ye, Q., Li, T. and Law, R. (2013) "A coauthorship network analysis of tourism and hospitality research collaboration", Journal of Hospitality \& Tourism Research, Vol. 37 No. 1, pp. 51-76.

Yeung, T. A. and Law, R. (2004) "Extending the modified heuristic usability evaluation technique to chain and independent hotel websites", International Journal of Hospitality Management, Vol. 23 No. 3, pp. 307-313.

Yilmaz, Y. and Bititci, U. S. (2006) "Performance measurement in tourism: a value chain model", International Journal of Contemporary Hospitality Management, Vol. 18, No. 4, pp. 341-349.

Yin, P., Tsai, H. and Wu, J. (2015) "A hotel life cycle model based on bootstrap DEA efficiency: The case of international tourist hotels in Taipei", International Journal of Contemporary Hospitality Management, Vol. 27, No. 5, pp. 918-937.

Yoo, M., Lee, S. and Bai, B. (2011) "Hospitality marketing research from 2000 to 2009: topics, methods, and trends", International Journal of Contemporary Hospitality Management, Vol. 23 No. 4, pp. 517-532.

Yuan, Y., Gretzel, U. and Tseng, Y. H. (2015) "Revealing the nature of contemporary tourism research: Extracting common subject areas through bibliographic coupling", International Journal of Tourism Research, Vol. 17 No. 5, pp. 417-431.

Zhao, X., Mattila, A. S. and Ngan, N. N. (2014) "The impact of frontline employees' work-family conflict on customer satisfaction: The mediating role of exhaustion and emotional displays", Cornell Hospitality Quarterly, Vol. 55, No. 4, pp. 422-432.

Zhu, Y., Sun, L. Y. and Leung, A. S. (2014) "Corporate social responsibility, firm reputation, and firm performance: The role of ethical leadership", Asia Pacific Journal of Management, Vol. 31, No. 4, pp. 925-947. 
Appendix 1. Previous published reviews

\begin{tabular}{|c|c|c|c|c|c|c|c|c|c|c|}
\hline Paper & Journals & Discipline & $\begin{array}{c}\text { Sample } \\
\text { size }\end{array}$ & $\begin{array}{c}\text { Sample } \\
\text { selection }\end{array}$ & Used keywords & $\begin{array}{c}\text { Journals (JOU) or databases } \\
\text { (DB) }\end{array}$ & Year & Text analysis & Findings & $\begin{array}{l}\text { Google } \\
\text { citations }\end{array}$ \\
\hline $\begin{array}{l}{ }_{1} \text { Assaf and } \\
\text { Josiassen (2012) }\end{array}$ & JTR & Efficiency & $\begin{array}{c}\text { Not } \\
\text { specified }\end{array}$ & Not specified & Not specified & Not specified & $\begin{array}{c}\text { Not } \\
\text { specified }\end{array}$ & $\begin{array}{l}\text { Content } \\
\text { analysis }\end{array}$ & $\begin{array}{l}\text { Determinants of tourism } \\
\text { performance and their } \\
\text { relative importance }\end{array}$ & 74 \\
\hline $\begin{array}{l}\text { Tsionas and } \\
\text { Assaf (2014) } \\
\end{array}$ & TM & Efficiency & 6 & Not specified & Not specified & Not specified & $\begin{array}{c}\text { Not } \\
\text { specified }\end{array}$ & $\begin{array}{l}\text { Content } \\
\text { analysis }\end{array}$ & $\begin{array}{c}\text { New dynamic stochastic } \\
\text { frontier model }\end{array}$ & 20 \\
\hline $\begin{array}{l}3 \text { Janković and } \\
\text { Krivačić (2014) }\end{array}$ & THM & $\begin{array}{c}\text { Environmental } \\
\text { management }\end{array}$ & 29 & $\begin{array}{l}\text { Authors' } \\
\text { research }\end{array}$ & Authors' research & Authors' research & 10 & $\begin{array}{l}\text { Content } \\
\text { analysis }\end{array}$ & $\begin{array}{c}\text { Determine the } \\
\text { development of hotel } \\
\text { environmental accounting } \\
\text { practices }\end{array}$ & 7 \\
\hline $\begin{array}{l}4 \text { Chan and Hsu } \\
\text { (2016) }\end{array}$ & $\mathrm{IJCHM}$ & $\begin{array}{l}\text { Environmental } \\
\text { management }\end{array}$ & 149 & Keywords & $\begin{array}{c}\text { Environmental, energy } \\
\text { and water saving, } \\
\text { green practices, green } \\
\text { customers } \\
\end{array}$ & JOU: 4 hospitality journals & 22 & $\begin{array}{l}\text { Content } \\
\text { analysis }\end{array}$ & $\begin{array}{l}\text { Research topics; research } \\
\text { trends; research gaps }\end{array}$ & 9 \\
\hline $\begin{array}{l}5 \text { Jang and Park } \\
\text { (2011) }\end{array}$ & IJCHM & Finance & 113 & Not specified & Not specified & JOU: 4 hospitality journals & 20 & $\begin{array}{l}\text { Content } \\
\text { analysis }\end{array}$ & $\begin{array}{c}\text { Subject areas; } \\
\text { methodologies; citations }\end{array}$ & 39 \\
\hline 6 Tsai et al. (2011) & IJCHM & Finance & 98 & Keywords & 19 financial keywords & DB: ABI/INFORM & 12 & $\begin{array}{l}\text { Content } \\
\text { analysis }\end{array}$ & $\begin{array}{c}\text { Review hospitality financial } \\
\text { research }\end{array}$ & 32 \\
\hline $\begin{array}{l}7 \text { Park and Jang } \\
(2014)\end{array}$ & IJCHM & Finance & 22 & Not specified & Not specified & Not specified & 17 & $\begin{array}{l}\text { Content } \\
\text { analysis }\end{array}$ & $\begin{array}{l}\text { Interdisciplinary research in } \\
\text { finance and accounting }\end{array}$ & 12 \\
\hline $\begin{array}{l}\text { Lucas and Deery } \\
(2004)\end{array}$ & IJHM & HRM & 103 & Keywords & $\begin{array}{c}\text { Many (see Table 1, } 2 \text {, } \\
3,4,5)\end{array}$ & JOU: 5 hospitality journals & 2 & $\begin{array}{l}\text { Content } \\
\text { analysis }\end{array}$ & $\begin{array}{c}\text { Subject areas of HRM; } \\
\text { topical and emergent } \\
\text { issues; journals } \\
\end{array}$ & 102 \\
\hline $9 \begin{array}{l}\text { Davidson et al. } \\
\text { (2011) }\end{array}$ & IJCHM & HRM & $\begin{array}{c}\text { Not } \\
\text { specified }\end{array}$ & Not specified & Not specified & Not specified & $\begin{array}{c}\text { Not } \\
\text { specified }\end{array}$ & $\begin{array}{l}\text { Content } \\
\text { analysis }\end{array}$ & $\begin{array}{l}\text { Review the past, current } \\
\text { and future trends in human } \\
\text { resource management }\end{array}$ & 121 \\
\hline $10 \begin{array}{l}\text { Sourouklis and } \\
\text { Tsagdis (2013) }\end{array}$ & IJHM & HRM & 23 & Keywords & Many (see page 395) & $\begin{array}{l}\text { DB: ABI Inform Global; } \\
\text { Academic Search Elite; } \\
\text { Business Source Premier; } \\
\text { Emerald Management } \\
\text { Research; Pro-Quest } \\
\text { Education; Sage Publications }\end{array}$ & 22 & $\begin{array}{l}\text { Content } \\
\text { analysis }\end{array}$ & $\begin{array}{l}\text { Conceptual framework } \\
\text { depicting construct- } \\
\text { relations }\end{array}$ & 18 \\
\hline 11 Sainaghi (2010a) & IJCHM & Management & 152 & Keywords & Hotel \& performance & $\begin{array}{l}\text { DB: Science Direct; Business } \\
\text { Source Complete; EbscoHost } \\
\text { EJS }\end{array}$ & 20 & $\begin{array}{l}\text { Content } \\
\text { analysis }\end{array}$ & $\begin{array}{l}\text { lindipendent variables; } \\
\text { dimensions and indicators } \\
\text { of performance; research } \\
\text { design; } 3 \text { research styles }\end{array}$ & 126 \\
\hline
\end{tabular}


Appendix 1. Previous published reviews (continue)

\begin{tabular}{|c|c|c|c|c|c|c|c|c|c|c|}
\hline Paper & Journals & Discipline & $\begin{array}{c}\text { Sample } \\
\text { size }\end{array}$ & $\begin{array}{c}\text { Sample } \\
\text { selection }\end{array}$ & Used keywords & $\begin{array}{l}\text { Journals (JOU) or databases } \\
\text { (DB) }\end{array}$ & Year & Text analysis & Findings & $\begin{array}{c}\text { Google } \\
\text { citations }\end{array}$ \\
\hline 12 Sainaghi (2010b) & TR & Management & 138 & Keywords & Hotel \& performance & $\begin{array}{l}\text { DB: Science Direct; Business } \\
\text { Source Complete; Emerald }\end{array}$ & 20 & $\begin{array}{l}\text { Content } \\
\text { analysis }\end{array}$ & $\begin{array}{l}\text { Performance measurement } \\
\text { systems; determinants of } \\
\text { results organized around } \\
\text { the balanced scorecard }\end{array}$ & 22 \\
\hline $13 \begin{array}{l}\text { Sainaghi et al. } \\
(2013)\end{array}$ & IJHM & Management & 138 & Keywords & Hotel \& performance & JOU: 7 leading journals & 20 & $\begin{array}{l}\text { Content } \\
\text { analysis }\end{array}$ & $\begin{array}{l}\text { Balanced scorecard } \\
\text { perspectives included in } \\
\text { hotel performance } \\
\text { research; trends; } \\
\text { geographical areas }\end{array}$ & 70 \\
\hline $\begin{array}{ll}14 & \begin{array}{l}\text { Phillips and } \\
\text { Moutinho (2014) }\end{array} \\
\end{array}$ & TM & Management & 77 & Keywords & Strategic \& planning & JOU: 7 leading journals & 19 & $\begin{array}{l}\text { Content } \\
\text { analysis }\end{array}$ & Methods; topics; strategy & 41 \\
\hline $\begin{array}{l}\text { Pnevmatikoudi } \\
15 \text { and Stavrinoudis } \\
\text { (2016) } \\
\end{array}$ & EJTR & Management & 79 & Keywords & Hotel \& performance & DB: major databases & 29 & $\begin{array}{l}\text { Content } \\
\text { analysis }\end{array}$ & $\begin{array}{l}\text { Financial and non-financial } \\
\text { performance indicators }\end{array}$ & 2 \\
\hline $16 \begin{array}{l}\text { Sainaghi et al. } \\
\text { (2017) }\end{array}$ & TM & Management & 978 & Keywords & Hotel \& performance & DB: Scopus & 19 & $\begin{array}{c}\text { Computer- } \\
\text { Aided Text } \\
\text { Analysis (CATA) } \\
\end{array}$ & $\begin{array}{l}\text { Unit of analysis; } \\
\text { approaches; disciplines }\end{array}$ & 14 \\
\hline $17 \begin{array}{l}\text { Tsang and Hsu } \\
\text { (2011) }\end{array}$ & IJHM & $\begin{array}{l}\text { Management } \\
\text { (China) }\end{array}$ & 119 & Keywords & $\begin{array}{l}\text { China, hospitality, } \\
\text { tourism, visitors }\end{array}$ & $\begin{array}{l}\text { DB: Hospitality and Tourism } \\
\text { Index; Sage Journals Online; } \\
\text { ScienceDirect; Emerald } \\
\text { Insight. JOU: } 6 \text { leading } \\
\text { journals }\end{array}$ & 31 & $\begin{array}{l}\text { Content } \\
\text { analysis }\end{array}$ & $\begin{array}{c}\text { Themes; disciplines; } \\
\text { institutions; authorship; } \\
\text { methods }\end{array}$ & 86 \\
\hline $18 \begin{array}{l}\text { Gross et al. } \\
\text { (2013) }\end{array}$ & TMP & $\begin{array}{l}\text { Management } \\
\text { (China) }\end{array}$ & 115 & $\begin{array}{l}\text { Previous } \\
\text { study and } \\
\text { keywords }\end{array}$ & Hotel \& China & $\begin{array}{l}\text { DB: Hospitality and Tourism } \\
\text { Complete; Science Direct }\end{array}$ & 26 & $\begin{array}{l}\text { Content } \\
\text { analysis }\end{array}$ & $\begin{array}{l}\text { Content analysis of } \\
\text { research themes and trends } \\
\text { in China hotel research }\end{array}$ & 28 \\
\hline $19 \begin{array}{l}\text { Solnet et al. } \\
(2010)\end{array}$ & CIT & Marketing & $\begin{array}{c}\text { Not } \\
\text { specified }\end{array}$ & Not specified & Not specified & Not specified & $\begin{array}{c}\text { Not } \\
\text { specified }\end{array}$ & $\begin{array}{l}\text { Content } \\
\text { analysis }\end{array}$ & $\begin{array}{c}\text { Assess the literature on } \\
\text { decline and turnarounds } \\
\text { and propose an agenda for } \\
\text { future research }\end{array}$ & 25 \\
\hline 20 Yoo et al. (2011) & IJCHM & Marketing & 570 & Not specified & Not specified & JOU: 4 hospitality journals & 10 & $\begin{array}{l}\text { Content } \\
\text { analysis }\end{array}$ & $\begin{array}{c}\text { Topical areas; industry } \\
\text { applications; methods; } \\
\text { notable trends }\end{array}$ & 93 \\
\hline
\end{tabular}


Appendix 1. Previous published reviews (continue)

\begin{tabular}{|c|c|c|c|c|c|c|c|c|c|c|}
\hline Paper & Journals & Discipline & $\begin{array}{l}\text { Sample } \\
\text { size }\end{array}$ & $\begin{array}{c}\text { Sample } \\
\text { selection }\end{array}$ & Used keywords & $\begin{array}{l}\text { Journals (JOU) or databases } \\
\text { (DB) }\end{array}$ & Year & Text analysis & Findings & $\begin{array}{l}\text { Google } \\
\text { citations }\end{array}$ \\
\hline 21 Hua (2016) & IJCHM & Marketing & 155 & $\begin{array}{l}\text { snowballing } \\
\text { technique }\end{array}$ & Not used & $\begin{array}{c}\text { DB: Science Direct; ProQuest } \\
\text { Business; EbscoHost }\end{array}$ & $\begin{array}{c}\text { Not } \\
\text { specified }\end{array}$ & $\begin{array}{l}\text { Content } \\
\text { analysis }\end{array}$ & $\begin{array}{l}\text { Integrated framework of E- } \\
\text { commerce performance }\end{array}$ & 3 \\
\hline 22 Olsen (2004) & IJHM & Strategy & 32 & Not specified & Not specified & $\begin{array}{l}\text { Hospitality and non- } \\
\text { hospitality }\end{array}$ & 2 & $\begin{array}{l}\text { Content } \\
\text { analysis }\end{array}$ & $\begin{array}{c}\text { Environmental scanning; } \\
\text { strategic choices; resource- } \\
\text { based view }\end{array}$ & 62 \\
\hline $\begin{array}{l}\text { Harrington and } \\
23 \text { Ottenbacher } \\
(2011)\end{array}$ & IJCHM & Strategy & 225 & Not specified & Not specified & Leading hospitality journals & 5 & $\begin{array}{l}\text { Content } \\
\text { analysis }\end{array}$ & $\begin{array}{l}\text { Percentage of strategy } \\
\text { articles; identification of } \\
\text { key strategy topic areas }\end{array}$ & 68 \\
\hline
\end{tabular}

Google citations were collected the $28^{\text {th }}$ of October 2017. Journal acronyms: CIT $=$ Current Issues in Tourism; EJTR $=$ European Journal of Tourism Research; IJCHM $=$ International Journal of Contemporary Hospitality Management; IJHM = International Journal of Hospitality Management; TE = Tourism Economics; THM = Tourism and hospitality management; TM = Tourism Management; TMP = Tourism Management Perspectives; TR = Tourism Review. 